\title{
SHRIMP U-Pb age of the radiolarian-bearing Yoshiki Formation in Japan
}

\author{
MANCHUK NURAMKHAAN, KENJI HORIE \& KAZUHIRO TSUKADA
}

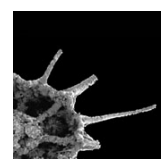

\begin{abstract}
The dating of radiolarian biostratigraphic zones from the Silurian to Devonian is only partially understood. Dating the zircons in radiolarian-bearing tuffaceous rocks has enabled us to ascribe practical ages to the radiolarian zones. To extend knowledge in this area, radiometric dating of magmatic zircons within the radiolarian-bearing Yoshiki Formation, Japan, was undertaken. The Yoshiki Formation is mainly composed of alternating beds of tuffaceous sandstones, tuffaceous mudstones, and felsic tuff. The felsic tuff and tuffaceous mudstone yield well-preserved radiolarian fossils. Radiolarians and zircon grains were collected from 21 tuffaceous mudstone and 30 tuff horizons of the Yoshiki Formation. The following radiolarian species which can be ascribed to the Zadrappolus yoshikiensis-Futobari solidus assemblage were identified: Oriundogutta(?) kingi, Oriundogutta(?) varispina, Zadrappolus yoshikiensis, Zadrappolus tenuis, Zadrappolus hitoeganensis, Zadrappolus lunaris, Zadrappolus(?) nudus, Zadrappolus(?) sp., Futobari solidus, Futobari morishitai, Rotasphaera(?) sp., and Ceratoikiscum armiger. $\mathrm{U}-\mathrm{Pb}$ SHRIMP ages of $420.5 \pm 2.5 \mathrm{Ma}$ and $421.0 \pm 1.9 \mathrm{Ma}$ were obtained from the zircon grains. Thus the lower limit of the Zadrappolus yoshikiensis-Futobari solidus assemblage, that has previously been assigned to an age from Př́idolian to Pragian, is in reality before Ludlowian. The technique in this paper has the capability of refining and making more accurate the dating of many radiolarian zones worldwide, and potentially of changing the direction of the entire study of radiolarian biostratigraphy. - Key words: U-Pb SHRIMP age, Silurian, Devonian, radiolarian, biostratigraphy.
\end{abstract}

MANCHUK, N., HORIE, K. \& TSUKADA, K. 2013. SHRIMP U-Pb age of the radiolarian-bearing Yoshiki Formation in Japan. Bulletin of Geosciences 88(2), 223-240 (13 figures). Czech Geological Survey, Prague. ISSN 1214-1119. Manuscript received February 3, 2012; accepted in revised form April 16, 2012; published online May 28, 2012; issued June 7 , 2013 .

Manchuk Nuramkhaan, School of Geology and Petroleum Engineering, Mongolian University of Science and Technology, P.O. Box 46/654, Ulaanbaatar 46-210646, Mongolia; manchukn@ gmail.com・Kenji Horie, National Institute of Polar Research, 10-3, Midoricho, Tachikawa, Tokyo 190-8518, Japan • Kazuhiro Tsukada, Nagoya University Museum, Chikusa, Nagoya 464-8601, Japan

Many studies have now given us a clear picture of worldwide post-Carboniferous radiolarian biostratigraphy, and radiolaria nowadays receive wide recognition as an important tool, especially in tectonics, for revealing the Earth's history. In contrast, the biostratigraphy of pre-Devonian radiolaria is still not well understood. Although studies of Silurian to Devonian radiolarians in Australia, North America, Urals and Japan have made significant advances in establishing biostratigraphic zonation, assigning an age to each zone is still controversial (Aitchison \& Stratford 1997, Aitchison et al. 1999, Amon et al. 1995, Furutani 1990, Kurihara 2004, Kurihara \& Sashida 2000, Noble 1994, Noble \& Aitchison 2000, Obut \& Shcherbanenko 2008, Stratford \& Aitchison 1997, Umeda 1998). Some Silurian to Devonian formations in Japan which yield radiolarian fossils are intercalated with felsic tuff layers with euhedral zircons. Determining the isotopic age of the zircons therefore enables us to confirm the practical ages of the $\mathrm{Si}$ lurian to Devonian radiolarian zones.

In order to determine the age of upper Silurian to Lower Devonian radiolarian zones, we have undertaken radiometric dating of magmatic zircons within the radiolarian bearing beds of the Yoshiki Formation in the Fukuji area, Takayama City, Southwest Japan.

\section{Geological outline of the Fukuji area}

The study area is in the Hida Gaien belt, Southwest Japan. The Hida Gaien belt is composed largely of Ordovician to Cretaceous sedimentary and volcanic rocks with minor amounts of ultramafic rocks and crystalline schist. This belt occurs in a narrow zone between the Hida belt, which is mainly composed of Paleozoic gneiss and meta-granite, 


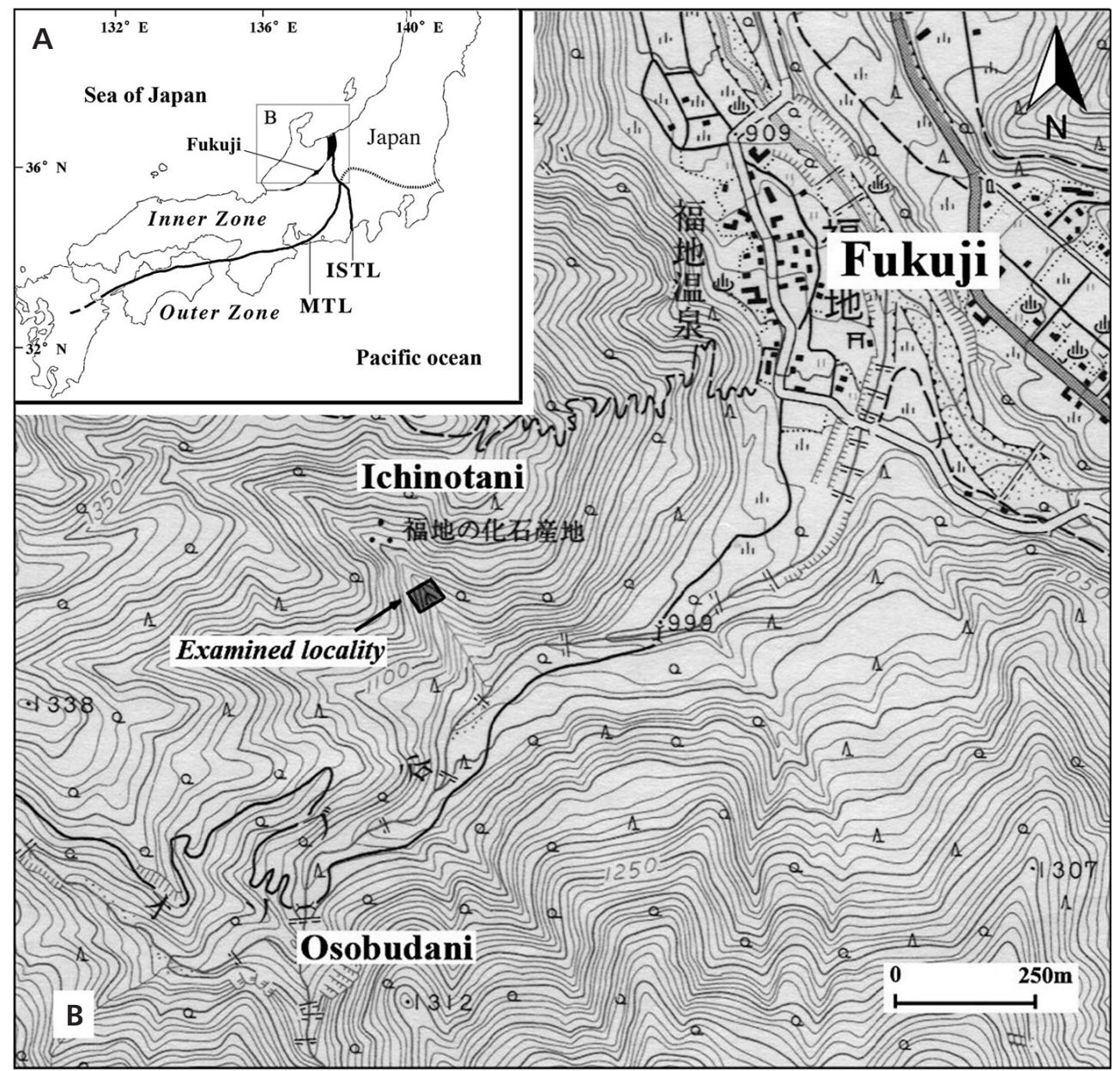

Figure 1. Index map of the study area. The topographical map is part of the 1:25,000 scale map sheet "Yakedake" published by the Geospatial Information Authority of Japan.

and the Mino belt, which is composed of Jurassic to Cretaceous accretionary complexes.

The Paleozoic rocks in the Fukuji area trend ENE and are divided into the following five formations in ascending order; 1) upper Silurian (?) to Devonian Yoshiki Formation (felsic tuff and tuffaceous clastic rocks), 2) Devonian Fukuji Formation (mainly limestone), 3) Carboniferous Ichinotani Formation (mainly limestone), 4) Lower Permian Mizuyagadani Formation (mainly clastic rocks), 5) Lower Permian Sorayama Formation (mainly mafic volcanic rocks) (e.g. Igo 1990, Tsukada \& Takahashi 2000). The Yoshiki Formation is unconformably overlain by the Fukuji Formation (Igo 1990, Kurihara 2003). Although the Fukuji, Ichinotani, and Mizuyagadani formations are in fault contact with each other, they are likely to form conformable or unconformable succession. The Sorayama Formation conformably overlies the Mizuyagadani Formation (Tsukada et al. 1999, Tsukada \& Takahashi 2000). The Paleozoic formations in the Fukuji area are folded around the axis that plunges steeply southeast, and are cut by several younger North-south sub-vertical oblique-slip faults (Tsukada et al. 1999, Tsukada \& Takahashi 2000). All these formations are intruded by many small dikes of felsic to intermediate rocks, and are unconformably covered by Cenozoic volcaniclastic rocks.

The Yoshiki Formation is mainly composed of alternating beds of tuffaceous sandstone, tuffaceous mudstone and felsic tuff and it yields well-preserved radiolarian fossils. Although this formation was once believed to be Ordovician in age, based on the ostracods from a mudstone float beside outcrop (Igo et al. 1980), it is now assigned to from upper Silurian to Lower Devonian as a result of recent radiolarian studies (Kurihara 2004).

\section{Geological description of the Yoshiki Formation}

The stratotype section of the Yoshiki Formation (Igo et al. 1980, Tsukada et al. 1999) along the Ichinotani Valley, south hillside of Mt. Sorayama, Fukuji area was examined in this study. Here, a $30 \mathrm{~m}$ thickness of fine- to coarse-grained felsic tuff and alternating beds of tuffaceous sandstone, tuffaceous mudstone and felsic tuff is continuously exposed. The rocks of this formation can be divided into lower, middle, and upper members. The 


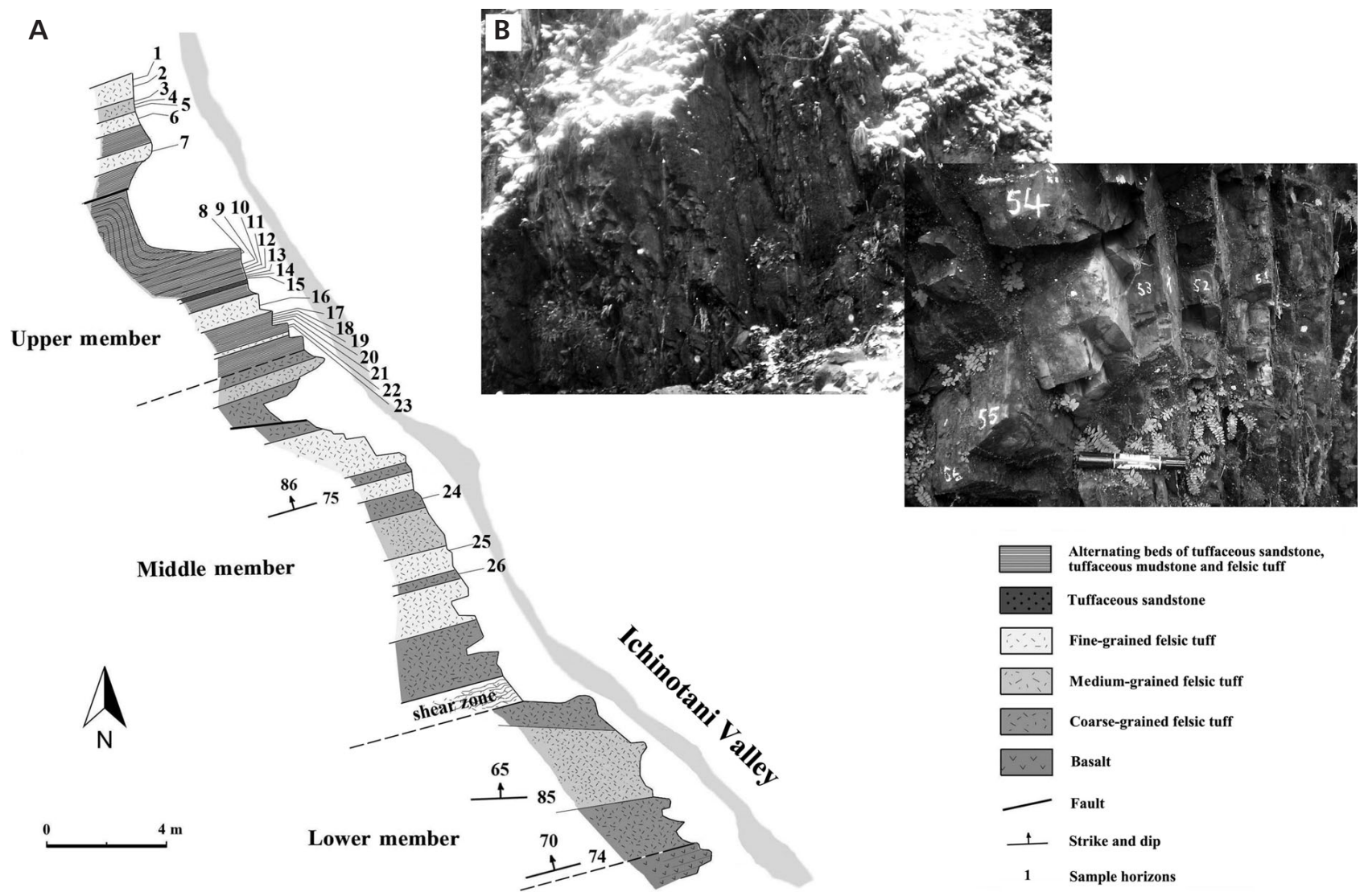

Figure 2. Route map showing lithology (a) and photographs showing the mode of occurrence of the alternating beds of fine-grained felsic tuff and tuffaceous mudstone in the upper member (b) of the Yoshiki Formation.

middle and lower members are mostly made up of bedded felsic tuff intercalated with characteristic coarse-grained tuff layers. The upper member consists mainly of alternating beds of tuffaceous sandstone, tuffaceous mudstone and felsic tuff. This formation, which trends east and dips steeply north, exhibits graded beddings indicating northward facing. The lower member is in fault contact with the middle member with a remarkable shear zone. The shear zone, one meter wide, is composed of fissile muddy cataclasite that trends NW-SE. The upper member conformably overlies the middle member. The upper member is folded with an axis that plunges steeply northeast.

The lower member consists of bedded medium- to coarse-grained felsic tuff (Fig. 3). Each bed, 5 to $7 \mathrm{~cm}$ thick, strikes $\mathrm{E}-\mathrm{W}$ to $\mathrm{N} 74^{\circ} \mathrm{E}$ and dips $65^{\circ}$ to $70^{\circ}$ north. Well-bedded fine- to coarse-grained felsic tuff is the major facies of the middle member. The felsic tuff exhibits graded beddings indicating northward facing, strikes $\mathrm{N} 75^{\circ} \mathrm{E}$ and dips $86^{\circ}$ north. Each bed is from 7 to $10 \mathrm{~cm}$ thick. The felsic tuff of the lower and middle members includes many phenocrysts of euhedral to subhedral laths of plagioclase, biotite, quartz and zircon with scattered flakes of opaque minerals, volcanic rock fragments and flattened pumice. A swirly mass of irregularly shaped altered volcanic glass shards is seen in some parts in the matrix of the tuff. Zircons are included not only in the matrix but also in the volcanic rock fragments. The upper member consists of alternating beds of tuffaceous sandstone, tuffaceous mudstone and fine-grained felsic tuff. The beds are graded, indicating northward facing, and each bed is from 5 to $10 \mathrm{~cm}$ thick. The fine-grained felsic tuff and tuffaceous mudstone generally includes radiolarian fossils (Fig. 4). Layers of coarse-grained felsic tuff, less than $7 \mathrm{~cm}$ thick, with numerous felsic volcanic rock fragments are intercalated in the alternating beds. The tuff of this member includes phenocrysts of euhedral to subhedral laths of plagioclase, biotite, quartz and zircon with scattered flakes of opaque minerals, volcanic rock fragments and flattened pumice similarly with that of the lower and middle members.

\section{Radiolarian fossils}

Radiolarians were recovered from the fine-grained felsic tuff and the tuffaceous mudstone by etching in dilute hydrofluoric acid for 24 hours. Individual radiolarians liberated from the matrix were washed and sieved at 63 and 


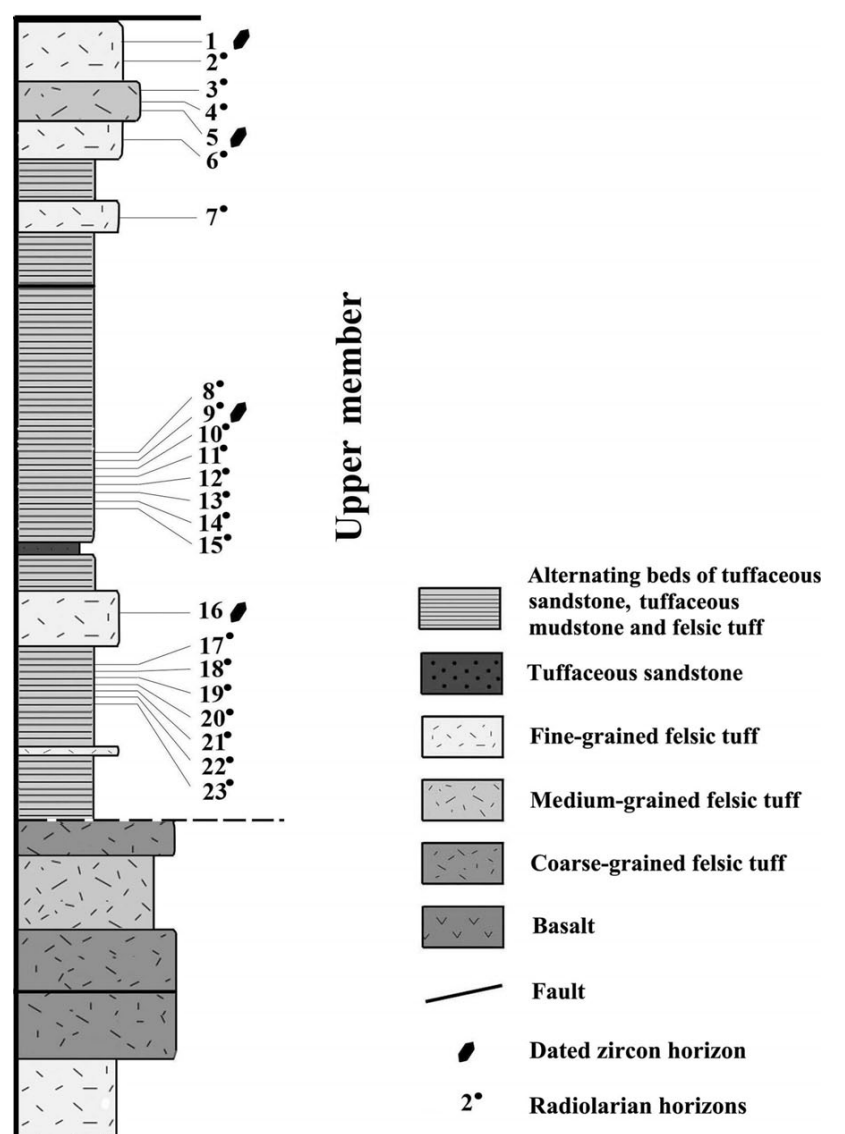

$\left.\right|_{0} ^{5 \mathrm{~m}}$

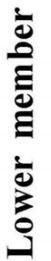

Figure 3. Columnar section of the Yoshiki Formation. 108-micron fractions. Radiolarians were picked from the dried residues and identified with the aid of reflected light and scanning electron microscopes. Well-preserved radiolarians were obtained only from the upper member, but some poorly-preserved unidentifiable radiolarians were also extracted from the middle member. The following species of radiolarians were identified from 15 tuffaceous mudstone and 5 fine-grained felsic tuff horizons of the upper member (Fig. 5); Oriundogutta(?) kingi, O.(?) varispina Noble, 1994, Zadrappolus yoshikiensis Furutani, 1990, Z. tenuis Furutani, 1990, Z. hitoeganensis Furutani, 1990, Z. lunaris Noble, 1994, Z.(?) nudus Kurihara 2007, Z.(?) sp. in Kurihara, 2007, Futobari solidus Furutani, 1990, F. morishitai Furutani, 1990, Rotasphaera(?) sp., Ceratoikiscum armiger Furutani, 1990. The most characteristic species of this assemblage is Z yoshikiensis, Z. tenuis, Z.(?) nudus, and F. solidus. The species present, $Z$. yoshikiensis, $Z$. tenuis, $F$. solidus and $F$. morishitai, are characteristic of the Z. yoshikiensis assemblage of Furutani (1990) that have been previously presumed to be latest Silurian to early Devonian (Furutani 1990). Kurihara (2007) proposed the $F$. solidus-Z. tenuis assemblage as an equivalent of the Z. yoshikiensis assemblage. Kurihara (2007) supposed that the F. solidus-Z. tenuis assemblage ranges from Přídolian to Pragian.

\section{Description of zircons and U-Pb SHRIMP age}

Eight rock samples, Nos. 1, 5, 9 and 16 from upper member and Nos. 24 to 26 from middle member, were used for U-Pb SHRIMP dating. Each sample ( $c a 1 \mathrm{~kg}$ ) was collected from a single outcrop. Zircons were concentrated using conventional mineral-separation techniques, including crushing and pulverizing, followed by separation using hand magnetic and heavy liquid techniques. About 233 zircon grains were mounted with standard materials in a mega-mount epoxy resin disc (Niihara et al. 2010), and diamond polished to expose the interior. In order to investigate internal structures of individual zircon grains, backscattered electron (BSE) images were obtained by electron probe microanalyzer (EPMA) and cathodoluminescense (CL) images by scanning electron microscope (SEM) at Nagoya University, Both images provided a guide for selection of the SHRIMP spots.

Observation and interpretation of zircon morphology is critical for understanding the isotopic data. For example, euhedral, concentric oscillatory zoning (in CL) and euhedral, prismatic external morphology are generally regarded as evidence for crystallization of zircon from a magma. In contrast, zircon that forms in a high-grade metamorphic environment tends to have patchwork zoning and a multifaceted, equant, tabular external morphology (Kroner et al. 2000, Pidgeon et al. 2000, van Breemen et al. 1986, Vavra et al. 1999). At very high metamorphic grade, these distinctions of origin become 

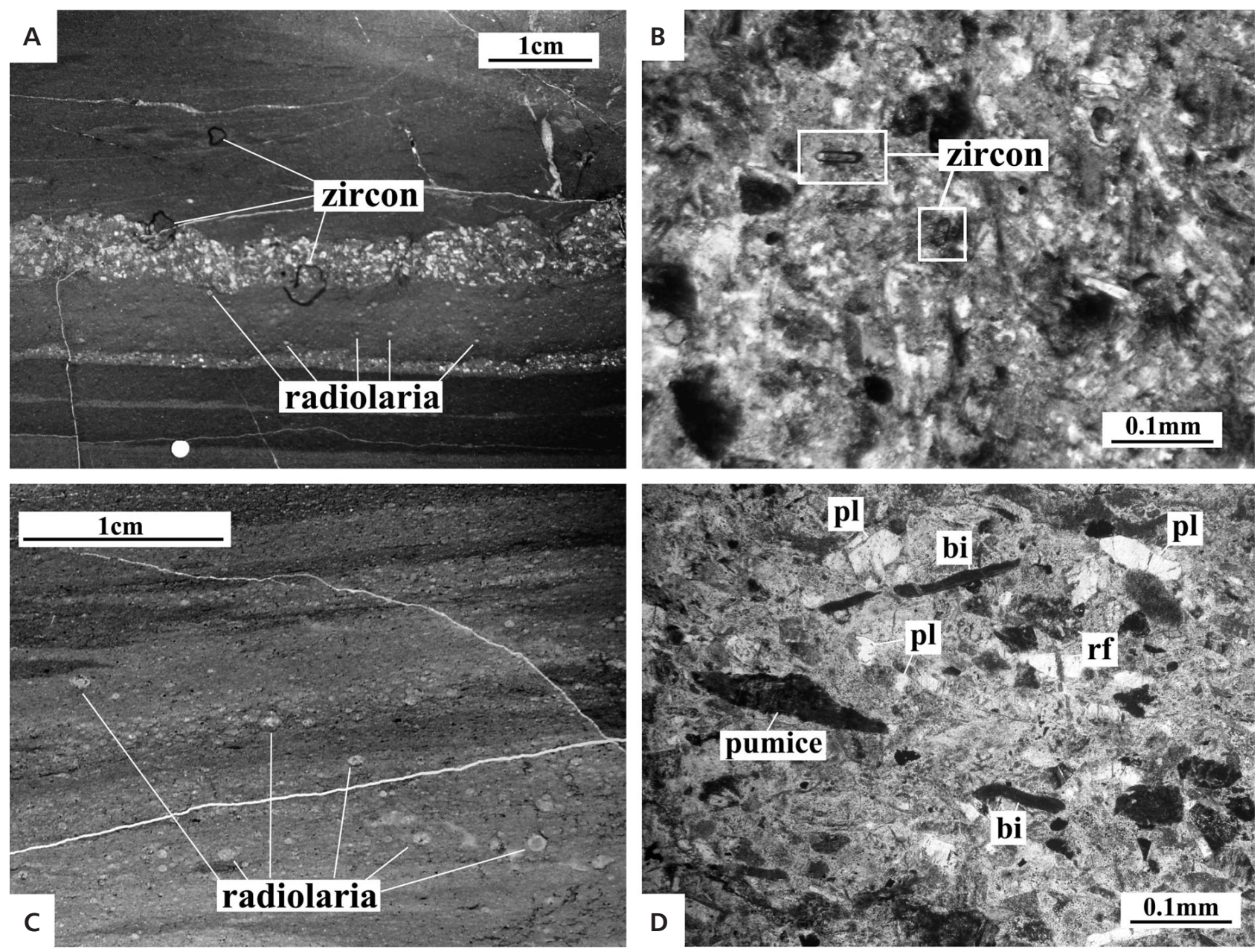

Figure 4. Thin section photomicrographs of rocks from the Yoshiki Formation. $\bullet$ A - tuffaceous mudstone with tuff intercalations containing zircons. - B - the fine-grained felsic tuff including zircons. $\bullet \mathrm{C}$ - tuffaceous mudstone including radiolarian fossils. Light gray dots show the radiolarian tests. - D - tuff with euhedral crystals of plagioclase (pl) and biotite (bi), volcanic rock fragments (rf) and flattened pumice.

Figure 5. A list of radiolarian fossils from the Yoshiki Formation. Black cells indicate presence.

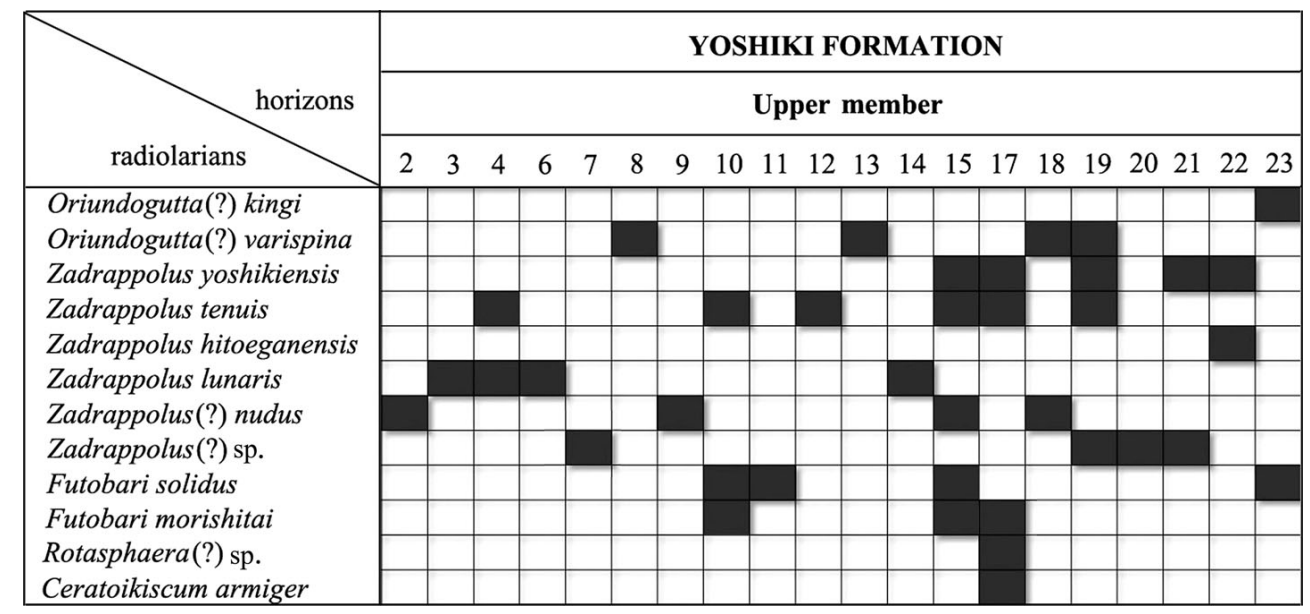

less obvious, particularly if metamorphic temperatures become high enough to cause partial melting. Under anatectic conditions, it becomes a semantic issue as to whether a zircon is considered to be igneous or metamorphic in origin. Zircons that have equant morphology occur in both igneous and sedimentary rocks and can superficially resemble equant zircons 


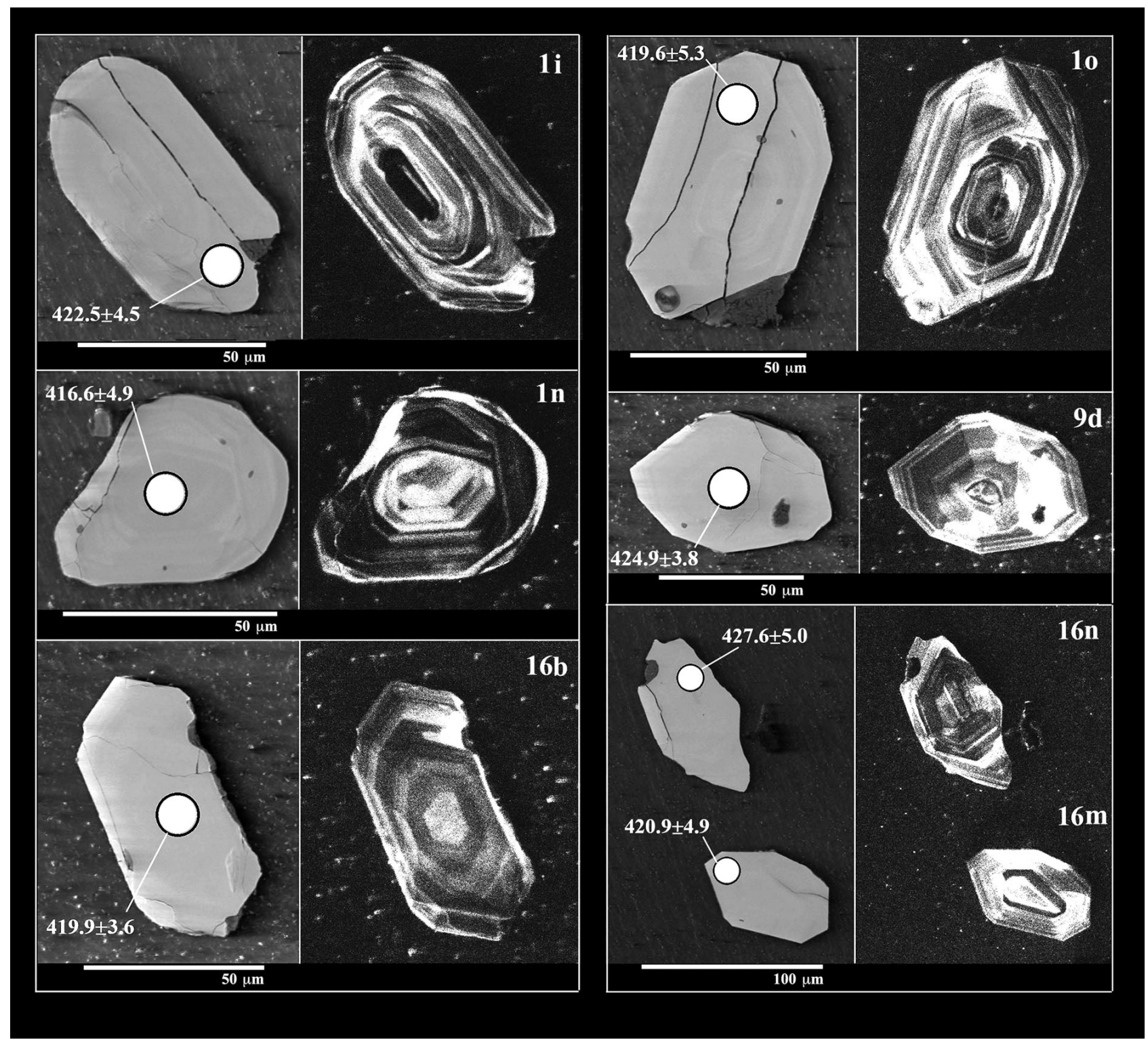

Figure 6. Scanning electron microscope (SEM, left side) and cathode luminescence (right side) images of representative zircons from the felsic tuff of the Yoshiki Formation. White circles on the SEM images show the SHRIMP analytical spots.

of metamorphic origin. However, equant igneous zircons can be distinguished from metamorphic zircons by their simpler crystallography (lower-order crystal faces) and concentric oscillatory zoning in CL. Equant zircons of detrital origin in sedimentary rocks tend to be spherical (not discoidal), usually have pitted or frosted, rounded surfaces (not flat faces), and truncated zoning in CL.

Fifteen zircon grains from sample 1, one from sample 5 , six from sample 9, fifteen from sample 16, two from sample 24, three from sample 25, fifty-one from sample 26 were analyzed. The analyzed zircons occur in different colors, including brown, yellow and colorless. The zircons are about $70 \mu \mathrm{m}$ in length and their length-to-width ratio is 2-1.5. These zircons mostly occur as subhedral to euhedral prisms, and commonly contain distinct cores with concentric zoning, consistent with crystallization from a viscous magma, and overgrowths (Fig. 6). The U-Pb zircon analyses were performed at 74 analytical spot on 67 grains. $\mathrm{U}-\mathrm{Pb}$ measurement was conducted using the SHRIMP at National Institute for Polar Research. An $\mathrm{O}_{2}$ primary ion beam of $\sim 1.5$ was used to sputter an analytical spot of $10 \mu \mathrm{m}$ diameter on the polished mount. The procedures for $\mathrm{Pb}$ and $\mathrm{U}$ isotopic analyses of zircon follow (Williams 1998, Horie et al. 2006). In this study, TEMORA2 $\left({ }^{206} \mathrm{~Pb} /{ }^{238} \mathrm{U}\right.$ age: $416.78 \pm 0.33 \mathrm{Ma}$ (Black et al. 2004$\left.)\right)$ and SL13 (U concentration: 238 ppm, Claoué-Long et al. 1995) were used as standard materials for the U-Pb analysis. The $\mathrm{U}-\mathrm{Pb}$ data were reduced by using the SQUID2 Excel macro 
of (Ludwig 2009). A correction for common $\mathrm{Pb}$ was made on the basis of the measured ${ }^{204} \mathrm{~Pb}$ and the model for common $\mathrm{Pb}$ compositions proposed by Stacey \& Kramers (1975). The pooled ages presented in this study are all after correction for common $\mathrm{Pb}$ and were calculated using the Isoplot/Ex software (Ludwig 2008). The SHRIMP analyses yieled concordant $\mathrm{U}-\mathrm{Pb}$ data are scattered from $\mathrm{ca}$ $410.2 \pm 4$ to $434.3 \pm 5.6 \mathrm{Ma}$ (Fig. 8). Weighted means of ${ }^{206} \mathrm{~Pb} /{ }^{238} \mathrm{U}$ ages are $\mathrm{ca} 420.5 \pm 2.5 \mathrm{Ma}$ (95\% confidence) in the upper member, and at ca $421.0 \pm 1.9 \mathrm{Ma}(95 \%$ confidence) in the middle member (Fig. 8).

\section{Discussion}

\section{Origin of zircons}

The felsic tuff of the Yoshiki Formation is of volcanic origin as evidenced by: (1) many euhedral to subhedral crystals of plagioclase, quartz and biotite are contained in the tuff, (2) many fragments of volcanic rock and flattened pumice parallel to the bedding plane are included, (3) the presence of irregularly shaped altered volcanic glass shards. All of the dated zircons occur as polygonal prisms, and show simple crystallography and concentric oscillatory zoning in CL. In addition, many volcanic rock fragments containing zircons are included in the tuff. If some of the dated zircons are detrital from an older source of rocks than the volcanism, bi- to multi-modal peaks of ages would be expected, however the results of SHRIMP dating clearly show a single peak of age around $420 \mathrm{Ma}$. This strongly suggests that the dated zircons were brought together with the other volcanic materials such as euhedral to subhedral crystals, volcanic rock fragments, pumice and glass, and their age is considered to be nearly same with the age of the age of the rock's sedimentation.

\section{Range of $F$. solidus- $Z$. tenuis assemblage}

Noble (1994) considered that the Z. yoshikiensis assemblage (Furutani 1990) of the Yoshiki Formation could be correlated with the upper part of her PraespongocoeliaStylosphaera(?) magnaspina zone to St.(?) magnaspina zone from Marathon uplift, USA due to the abundance of Z. yoshikiensis and Z. tenuis. These species are, however, not diagnostic because they range through the St.(?) magnaspina zone and into the Devoniglansus unicus-Rotasphaera zone as Noble (1994) has mentioned. In addition, Z. yoshikiensis and Z. tenuis were also reported from horizons above the Pseudospongoprunum sagittatum assemblage (Umeda 1998) and the Ps. tauversi assemblage (Kurihara 2004) which are correlative to the D. unicus-Ps.(?) tauversi zone of Noble (1994) (Kurihara 2004, Umeda

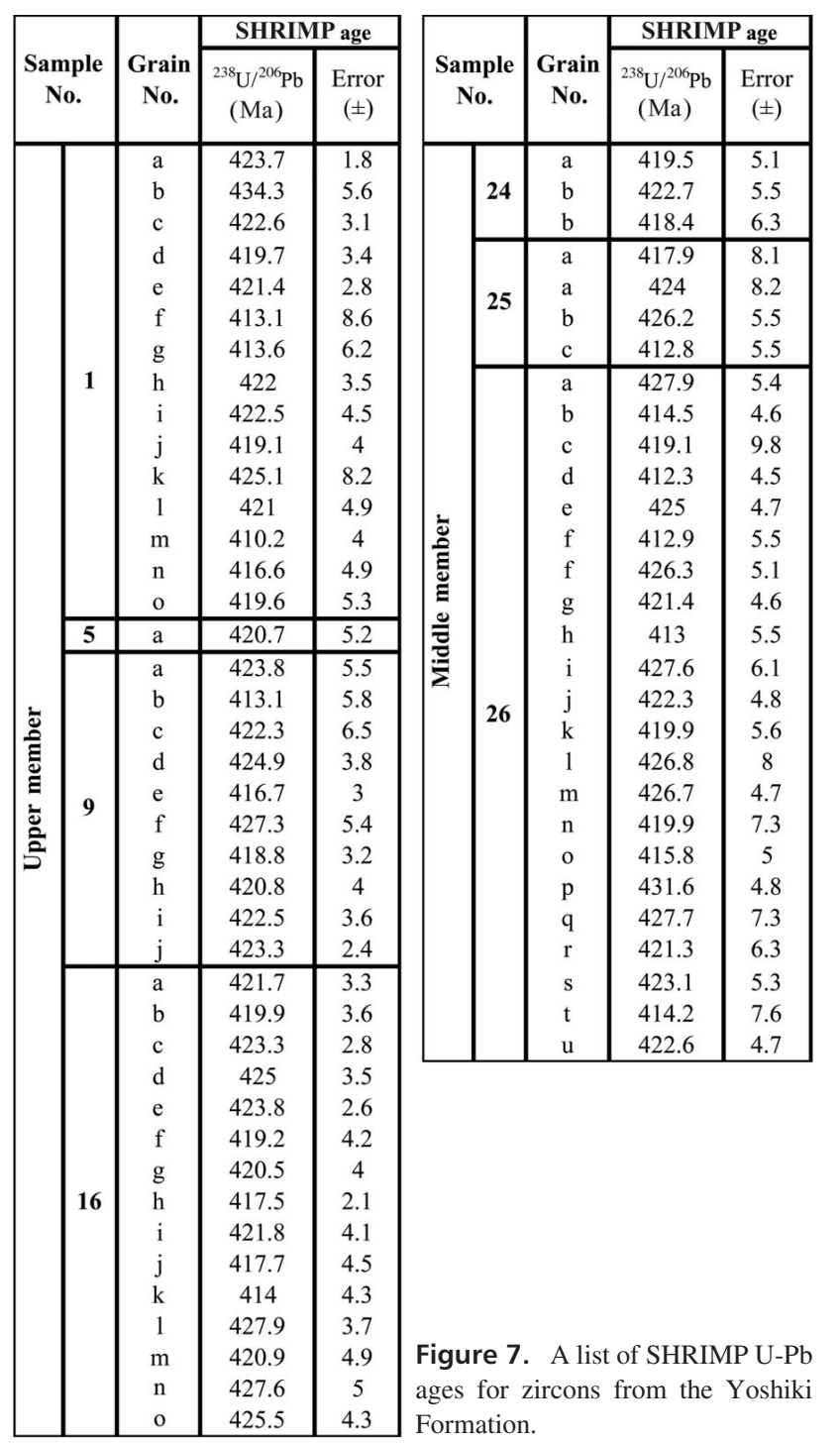

1998). Therefore, the Z. yoshikiensis assemblage is not correlated with the St.(?) magnaspina zone of Noble (1994).

Umeda (1998) and Kurihara (2004) put the equivalents of the $Z$. yoshikiensis assemblage $(F$. solidus assemblage in Umeda 1998 and the F. solidus-Z. tenuis assemblage in Kurihara 2004) above the D. unicus-Ps.(?) tauversi zone (Ps. sagittatum assemblage in Umeda 1998 and Ps. tauversi assemblage in Kurihara 2004) based on biostratigraphic correlation. The D. unicus-Ps.(?) tauversi zone has been assigned to the Prídolian because of the co-occurrence of a Ludlowian-Přídolian conodont fauna with in (Noble 1994), and Kurihara (2004) regarded the lower limit of the F. soli$d u s-Z$. tenuis assemblage as Přídolian. However, the co-yielding of the F. solidus-Z. tenuis assemblage and ca 420 Ma zircons in the present study suggests that the lower limit of the $F$. solidus-Z. tenuis assemblage might be before the Ludlowian, and therefore the D. unicus-Ps.(?) tauversi zone should more correctly to be assigned to the lower Ludlowian. 


\section{A. Upper member}

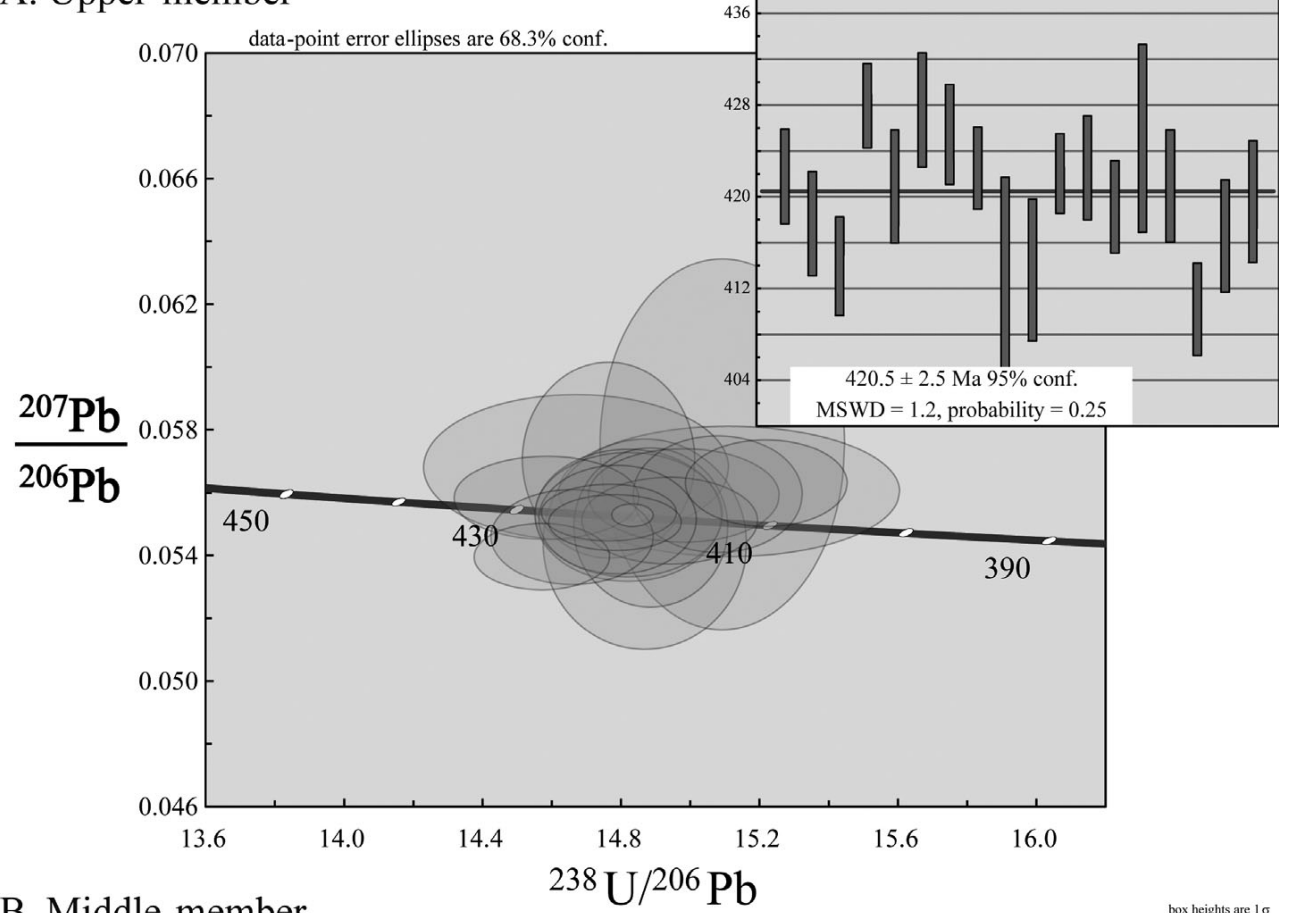

Figure 8. Tera-Wasserburg Concordia diagrams of zircon SHRIMP data. The U-Pb ages from analyses shown of error ellipse shading.

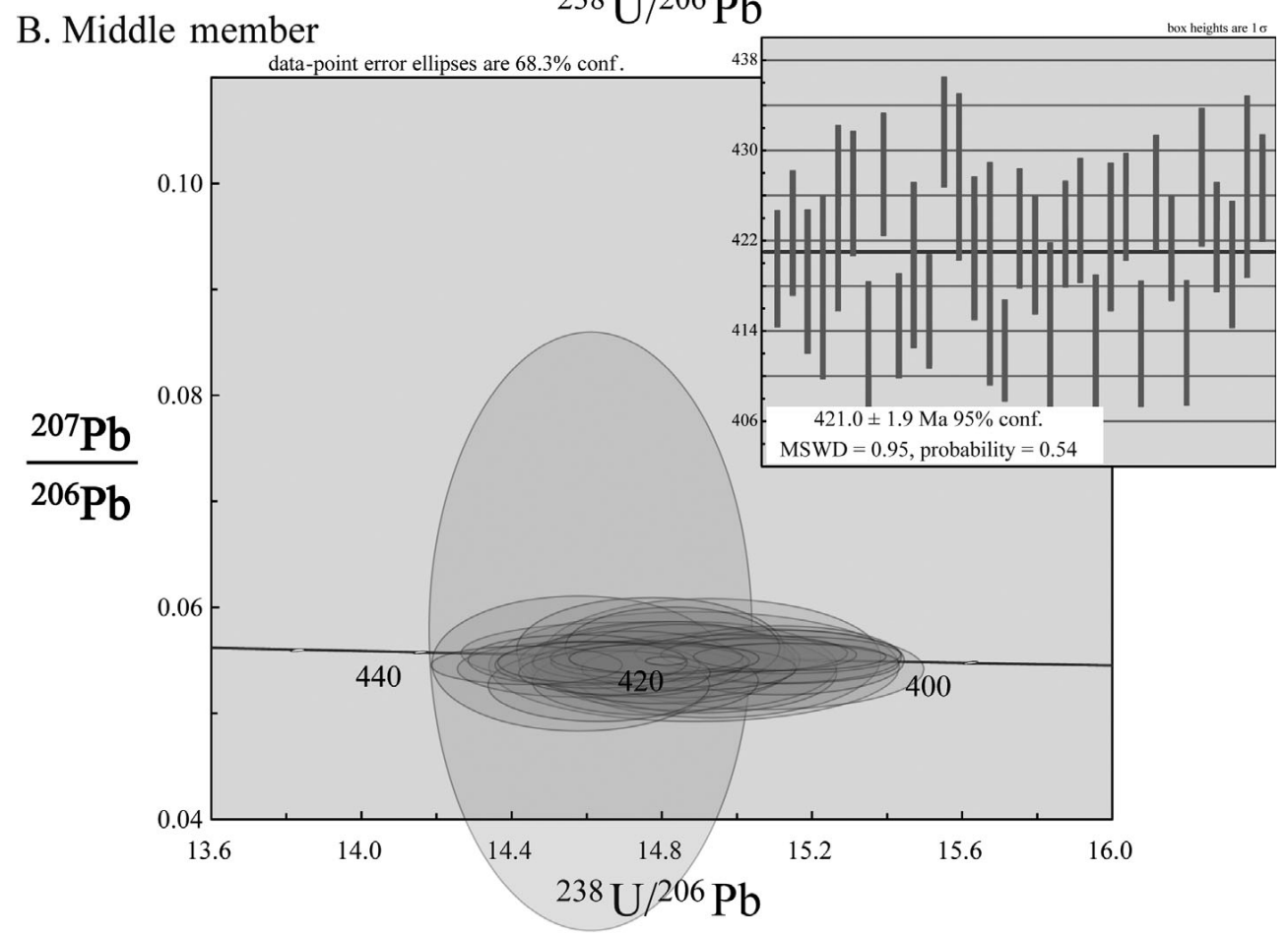

Aitchison et al. (1996) provided a U-Pb SHRIMP age of $408.9 \pm 7.6 \mathrm{Ma}$ using zircons from tuffaceous rock of the G4 Member (Yasui 1984) in the Kurosegawa terrane, Konomori area, Shikoku Island, Japan. They reported $F$. solidus and $F$. morishitai from the same locality as the zircons and so suggested that the Palaeoscenidium ishigai assemblage was assigned to the Silurian based on the geological time scale that existed at the time (Odin 1994).
But, Kurihara (2007) pointed out that the age $408.9 \pm$ 7.6 Ma is equivalent to the Pragian with error bars extending from the uppermost Př́dolian into the Emsian, based on a revaluation using the latest geologic time scale by Gradstein et al. (2004). In addition, the precise stratigraphic level of the dated zircon is unknown and it is not clear whether the age is practical in thinking the boundary between the $F$. solidus-Z. tenuis assemblage 


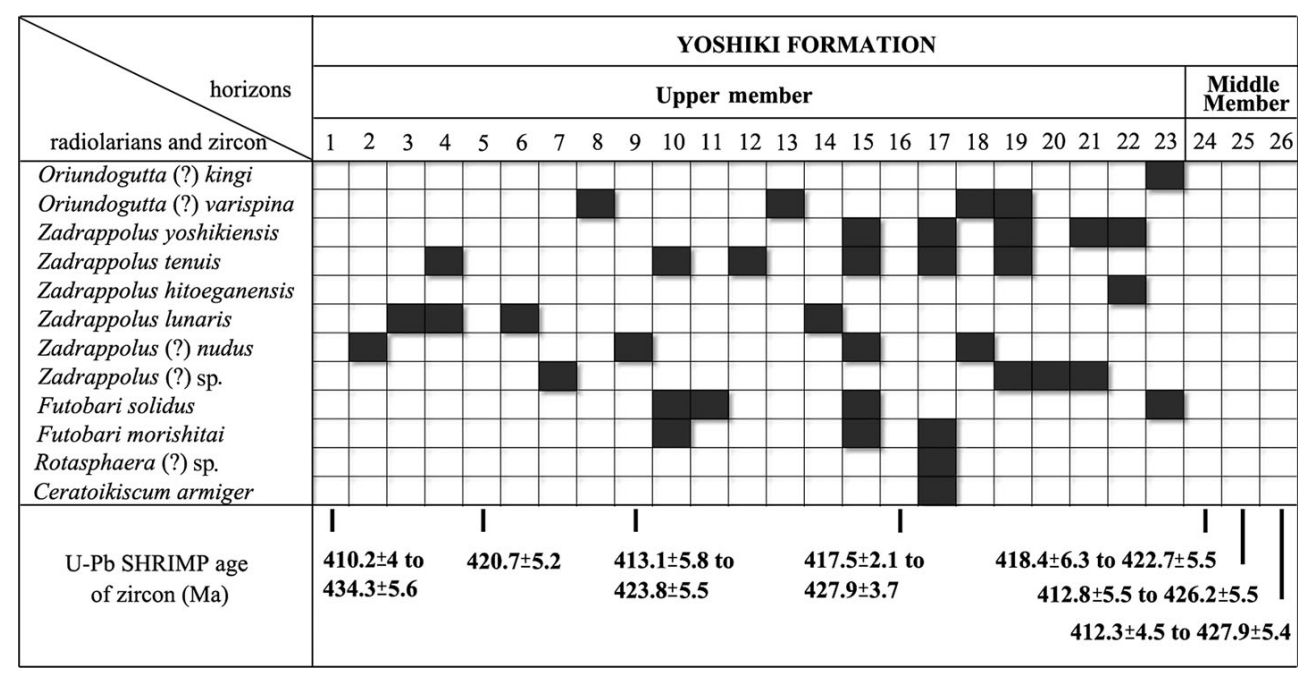

Figure 9. Summary of radiolarian and dated zircon horizons.

and the Pa. ishigai assemblage. Although Kurihara (2007), in his summary of radiolarian studies, suggested an Emsian upper limit for the F. solidus-Z. tenuis assemblage, the practical range of this assemblage is still open to discussion.

Dating the zircons in radiolarian-bearing tuffaceous rocks has enabled us to ascribe practical ages to the radiolarian zones in our study area. Detailed comparison between radiolarian assemblages and zircon radiometric ages is a technique that could be used elsewhere to determine the practical range of other early Paleozoic radiolarians. The technique has the capability of refining and making more accurate the dating of many radiolarian zones worldwide, and potentially of changing the direction of the entire study of radiolarian biostratigraphy.

\section{Systematic palaeontology}

Order Spumellaria Ehrenberg, 1875

Family Inaniguttidae Nazarov \& Ormiston, 1984, emend. Noble, 1994

\section{Genus Oriundogutta Nazarov, 1988}

Type species. - Astroentactinia ramificans Nazarov, 1975.

\section{Oriundogutta(?) kingi Noble, 1994}

Figure 11A

1988 Inanihella macroacantha (Rüst, 1892). - Nazarov, p. 209, pl. XII, fig. 1.

1993 Inanihella macroacantha? (Rüst 1892). - Nazarov \& Ormiston, p. 37, pl. 2, figs 6-8.

1994 Oriundogutta(?) kingi Noble, p. 31, pl. 6, figs 1, 4.

1998 Oriundogutta(?) kingi Kurihara \& Sashida, pl. 1, fig. 7 .
2000 Oriundogutta(?) kingi Kurihara \& Sashida, p. 58, pl. 1, figs 5,6 .

2003 Oriundogutta(?) kingi Kurihara, fig. 8-2.

1996 Oriundogutta? sp. cf. O. kingi Noble, 1994. - Aitchinson, Hada, Ireland \& Yoshikura, p. 67, pl. 2, fig. 15 .

2007 Oriundogutta(?) kingi Kurihara, p. 229, pl. 1, figs $15-18$.

Remarks. - This species is characterized by one thick cortical shell with 15 to 20 long robust spines per hemisphere. Spines are highly tapered at the proximal end and contain four to five grooves. Cortical shell is very large in diameter $(250 \mu \mathrm{m})$. Medullary shell is connected to cortical shell by rod-shaped primary bars. This species is superficially similar to species of Zadrappolus, especially Zadrappolus yoshikiensis. However, the structure and number of the medullary shells is still unclear in Oriundogutta(?) kingi, so its taxonomic position is tentative. This species differs from Oriundogutta(?) varispina Noble in possessing a larger number of robust spines and its shell is slightly smaller in diameter.

Range and occurrence. - Upper Silurian. Hitoegane area in the Hida-gaien terrane; Southern Urals; Marathon uplift in west Texas; Yoshiki Formation in the Hida-gaien terrane.

Oriundogutta(?) varispina Noble, 1994

Figure 11B-F

1994 Oriundogutta(?) varispina Noble, p. 31, pl. 6, figs 2, 3 , pl. 9 , fig. 4.

2007 Oriundogutta(?) varispina Kurihara, p. 229, pl. 1, figs 19, 20.

Remarks. - This species is characterized by a thick, latticed large cortical shell $270-300 \mu \mathrm{m}$ in diameter with 6 or more 


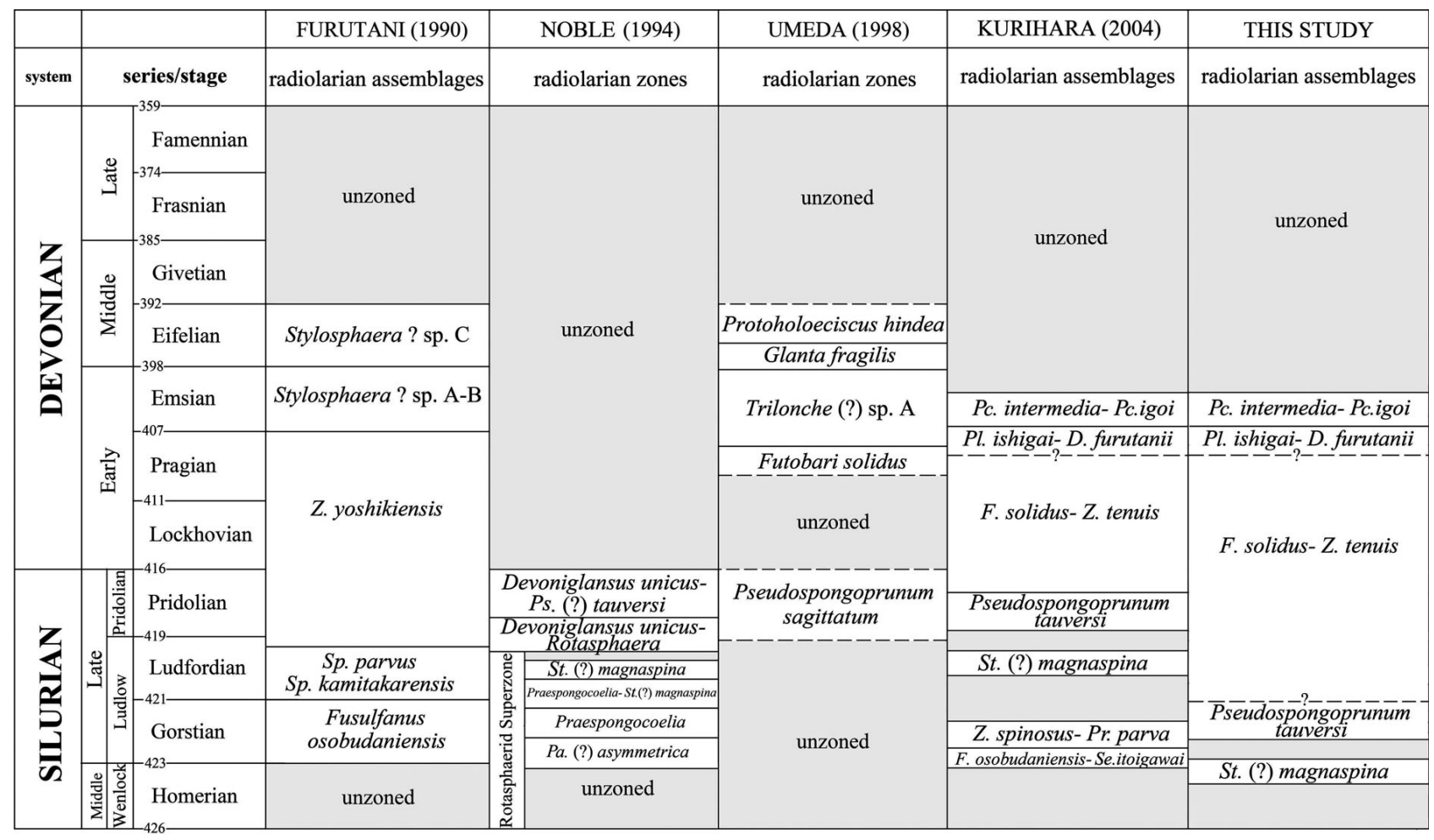

Figure 10. Comparison between the radiolarian assemblages and zones of Furutani (1990), Noble (1994), Umeda (1998), Kurihara (2004) and this study. Numerical ages (Ma) are from Gradstein et al. (2004).

robust external spines per hemisphere. The spine of this species, which is weakly grooved at its proximal portion and slightly to highly tapered, bears a strong morphological similarity to that of Oriundogutta(?) kingi Noble. This species, however, differs from $O$.(?) kingi in having thinner and fewer external spines.

Range and occurrence. - Uppermost Silurian. Hitoegane area in the Hida-gaien terrane; Marathon uplift in west Texas; Yoshiki Formation in the Hida-gaien terrane.

\section{Genus Zadrappolus Furutani, 1990}

Type species. - Zadrappolus yoshikiensis Furutani, 1990.

\section{Zadrappolus yoshikiensis Furutani, 1990}

Figures 11N-R, 12A-D

1990 Zadrappolus yoshikiensis Furutani, pp. 35, 36, pl. 2, figs 4-6; pl. 3, figs 1, 2.
1994 Zadrappolus yoshikiensis Noble, p. 32, pl. 6, figs 14-16.

1997 Zadrappolus yoshikiensis Umeda, p. 421, pl. 4, fig. 10.

1998 Zadrappolus yoshikiensis Kurihara \& Sashida, pl. 1, figs $1,2$.

2000 Zadrappolus yoshikiensis Kurihara \& Sashida, p. 58, pl. 1, figs 1,2 .

2007 Zadrappolus yoshikiensis Kurihara, p. 229, pl. 1, figs 21-24.

Remarks. - This species is characterized by a spherical cortical shell having 10 to 15 strongly tapered spines per hemisphere. The cortical shell is latticed and 120 to $200 \mu \mathrm{m}$ in diameter ( $150 \mu \mathrm{m}$ in average) based on 8 specimens. In the proximal part of the spines, 4 to 6 grooves are shallowly developed. Although two medullary shells have been observed by Furutani (1990), detailed structures are unknown, especially in the inner medullary shell. Zadrappolus tenuis differs from Z. yoshikiensis in bearing long and cylindrical spines. Zadrappolus yoshikiensis is distinguished from

Figure 11. A - Oriundogutta(?) kingi Noble. 1, horizon 23. • B-F-Oriundogutta(?) varispina Noble. B - horizon 13; C - horizon 18; D - horizon 19; E - horizon 8; F - horizon 8. • G-K - Futobari solidus Furutani. G - horizon 23; H - horizon 15; I - horizon 11; J - horizon 10; K - horizon 10. - L, M - Futobari morishitai Furutani. L - horizon 15; M - horizon 10. - N-R - Zadrappolus yoshikiensis Furutani. N - horizon 21; O - horizon 19; P - horizon 15; Q - horizon 17; R - horizon 17. Scale bars: $100 \mu \mathrm{m}$. 


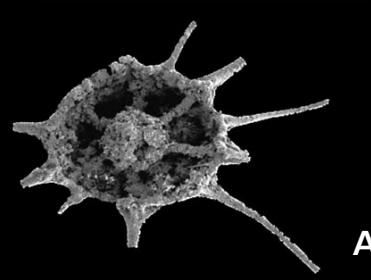

A

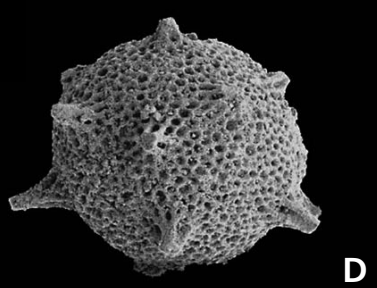

D
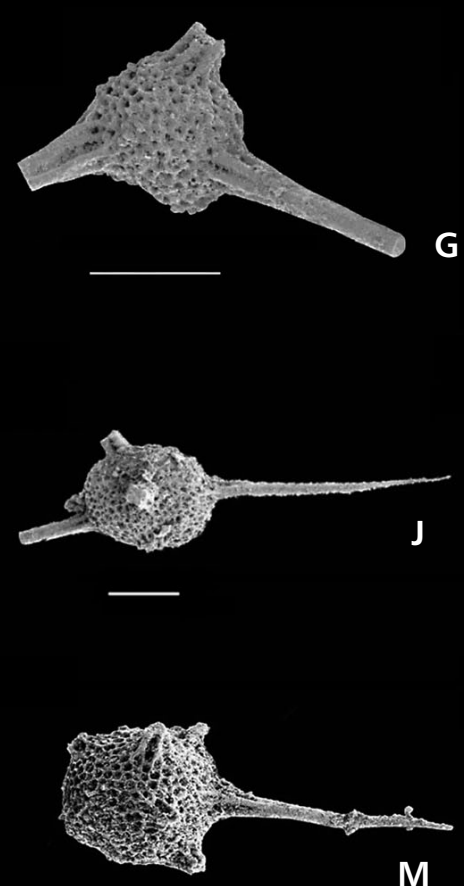

M

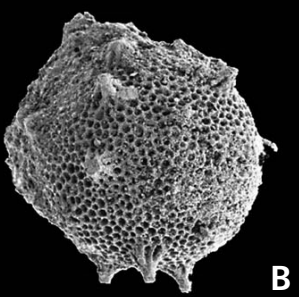

B

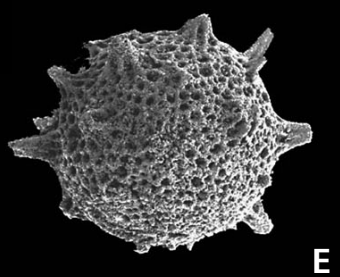

E
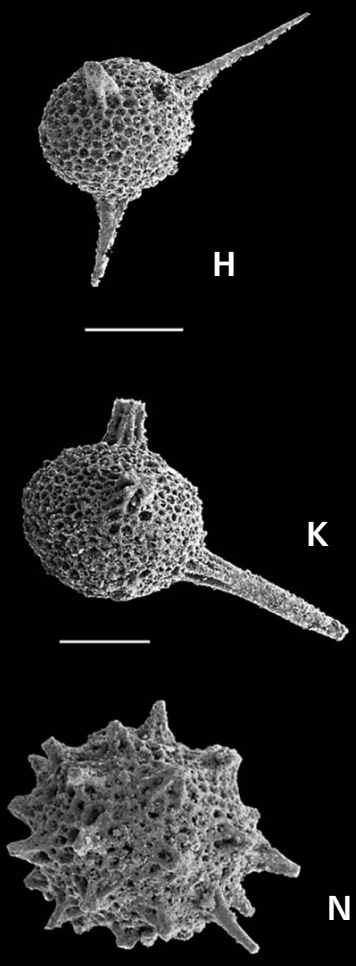

\section{N}

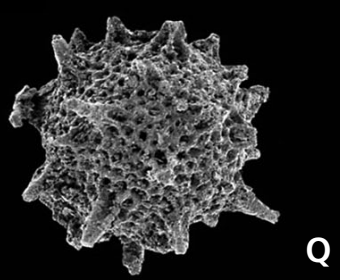

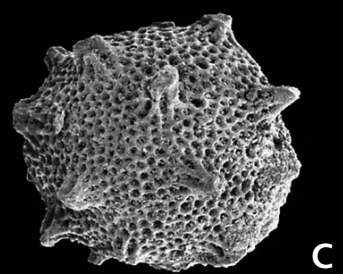
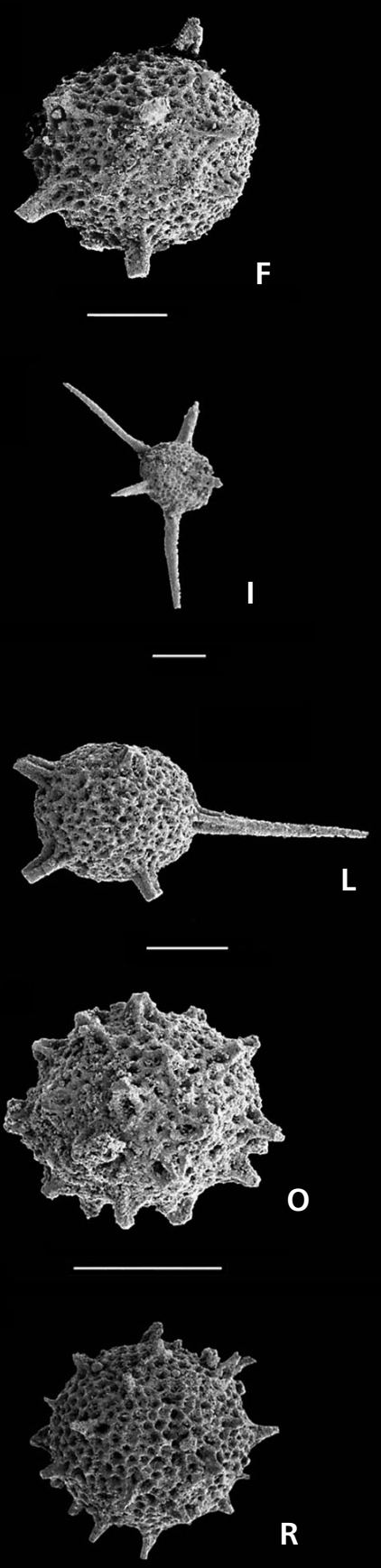

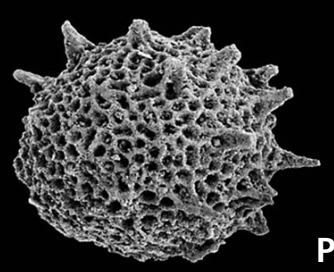


Zadrappolus spinosus and Zadrappolus hitoeganensis by its short, thin, and numerous cylindrical spines. Zadrappolus lunaris is similar to Z. yoshikiensis in external appearance; however, the former differs from the latter in having a larger cortical shell with a smaller number of conical spines. Zadrappolus nudus is distinguished from Z. yoshikiensis by possessing a larger cortical shell with few very small spines.

Range and occurrence. - Upper Silurian to Lower Devonian. Fukuji, Ise, Hitoegane areas and Yoshiki Formation in the Hida-gaien terrane; Konomori area of the Kurosegawa terrane in Southwest Japan; Marathon uplift in west Texas.

\section{Zadrappolus tenuis Furutani, 1990}

Figure 12E-P

1990 Zadrappolus tenuis Furutani, pp. 36, 37, pl. 3, figs 3-6.

1994 Zadrappolus tenuis Noble, p. 32, pl. 6, figs 10, $12,13$.

1996 Zadrappolus tenuis Aitchinson, Hada, Ireland \& Yoshikura, p. 67, pl. 1, figs 1, 6; pl. 2, fig. 6; pl. 3, figs $1,2,15$.

1998 Zadrappolus tenuis Kurihara \& Sashida, pl. 1, fig. 3 .

1998 Zadrappolus tenuis Umeda, fig. 9-7.

2000 Zadrappolus tenuis Kurihara \& Sashida, p. 58, pl. 1, fig. 3.

2007 Zadrappolus tenuis Kurihara, p. 230, pl. 1, figs 25-29.

1990 Spumellaria gen. indet sp. I Wakamatsu, Sugiyama \& Furutani, p. 177, pl. 3, figs 9-11.

1994 Zadrappolus sp. aff. Z. tenuis Furutani, 1990. Noble, p. 32, pl. 6, fig. 11.

1994 Inanihella aff. Macroacantha (Rüst, 1892). - Li, p. 421, pl. 2, figs 13,16 .

1997 Zadrappolus(?) tenuis Furutani, 1990. - Umeda, p. 421 , pl. 2, figs $8-15$.

1997 Zadrappolus(?) sp. aff. Z. tenuis Furutani, 1990. Umeda, p. 421, pl. 4, figs 11, 12.

Remarks. - Thick spherical, latticed shell 120-150 $\mu \mathrm{m}$ in diameter; 15 to 20 spines visible per hemisphere. Pores are rather regular in shape and size, round or ellipsoidal in shape. Spines are long and cylindrical but strongly tapered at proximal end with three grooves near base. This species differs from Zadrappolus spinosus and Zadrappolus hitoeganensis in possessing thicker and less numerous spines.

Range and occurrence. - Upper Silurian to Lower Devonian. Fukuji, Ise, Hitoegane areas and Yoshiki Formation in the Hida-gaien terrane; Konomori, Gionyama, Kasamigawa, and Jingamori areas in the Kurosegawa terrane; Marathon uplift in west Texas; Mayila area in west Junggar, China.

\section{Zadrappolus hitoeganensis Furutani, 1990} Figure 12Q

1990 Zadrappolus? hitoeganensis Furutani, pp. 37, 38, pl. 4, figs 5, 6; pl. 5, fig. 1.

2007 Zadrappolus hitoeganensis Kurihara, p. 230, pl. 2, figs 5-7.

Remarks. - This species is composed of a spherical cortical shell with more than 20 short external spines per hemisphere. Cortical shell diameter $140 \mu \mathrm{m}$. Shape and size of the pores variable round, oval, rounded-triangular, and rounded-recyangular in shape, 5-9 in diameter. This species is somewhat similar to Zadrappolus spinosus, except that it has a rather small shell diameter and a smaller number of external spines.

Range and occurrence. - Upper Silurian to Lower Devonian. Fukuji, Hitoegane areas and Yoshiki Formation in the Hida-gaien terrane.

\section{Zadrappolus lunaris Noble, 1994}

Figure 13A-D

1990 Spumellaria gen. indet. sp. D Wakamatsu, Sugiyama \& Furutani, p. 175, pl. 8, fig. 4.

1994 Zadrappolus lunaris Noble, pp. 32, 33, pl. 6, figs 7, 8; pl. 9 , fig. 8 .

2007 Zadrappolus lunaris Kurihara, p. 230, pl. 2, figs $8-10$.

Remarks. - Large spherical latticed cortical shell diameter 250 to $300 \mu \mathrm{m}$ with approximately 10 spines per hemisphere. Spines short, conical, and tapered distally. Spine bases are approximately 15 to $20 \mu \mathrm{m}$ in diameter and have 5 to 6 alternating grooves and ridges which are

Figure 12. A-D - Zadrappolus yoshikiensis Furutani. A - horizon 17; B - horizon 22; C - horizon 22; D - horizon 17. $\bullet$ E-P - Zadrappolus tenuis Furutani. E - horizon 19; F - horizon 15; G - horizon 15; H - horizon 10; I- horizon 12; J - horizon 10; K - horizon 15; L - horizon 4; M - horizon 17; $\mathrm{N}$ - horizon 17; $\mathrm{O}$ - horizon 10; P - horizon 17. • Q - Zadrappolus hitoeganensis Furutani; horizon 22. Scale bars: $100 \mu \mathrm{m}$. 


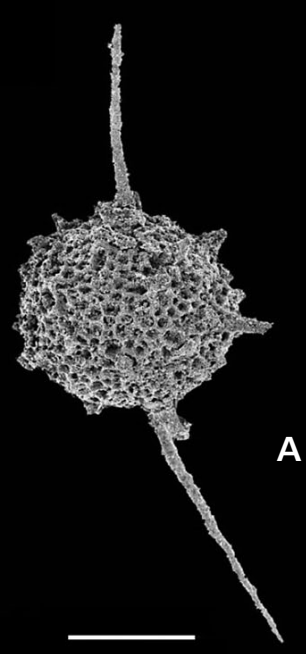

A
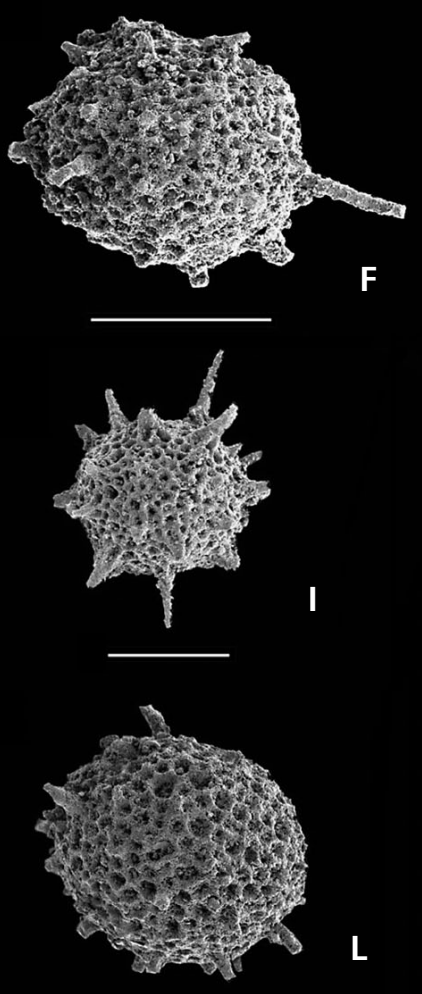

L

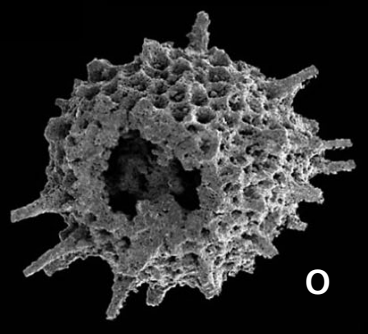

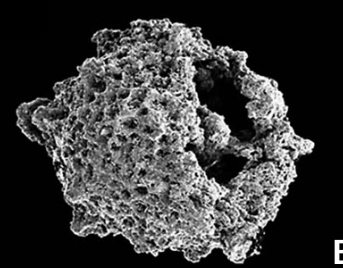

B

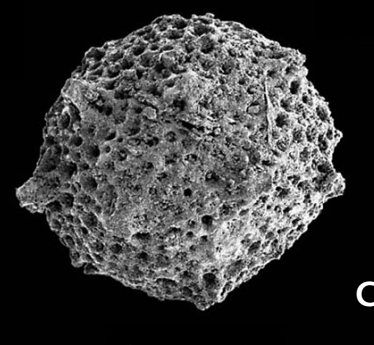

C
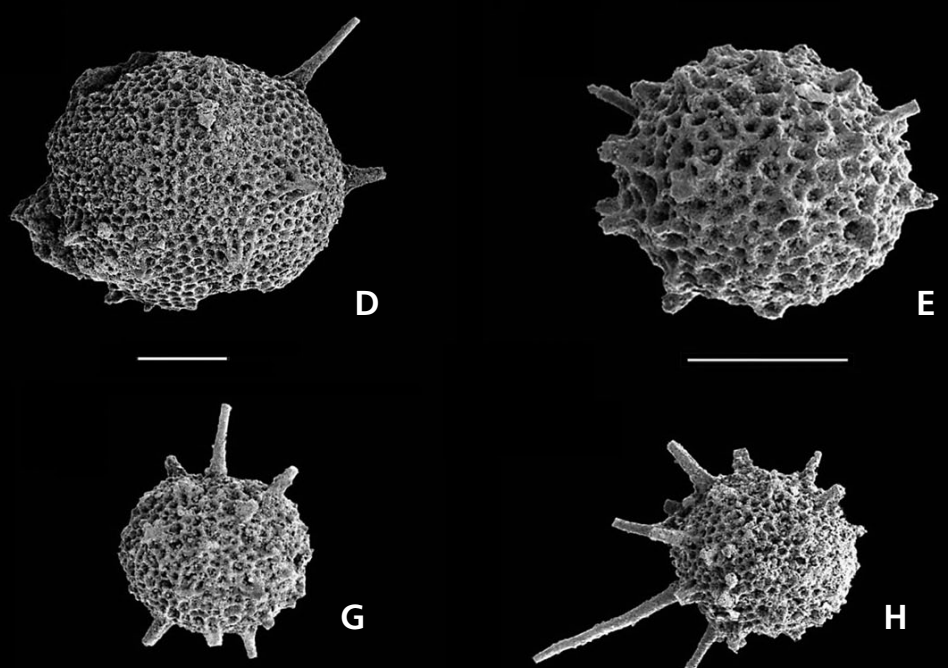

G
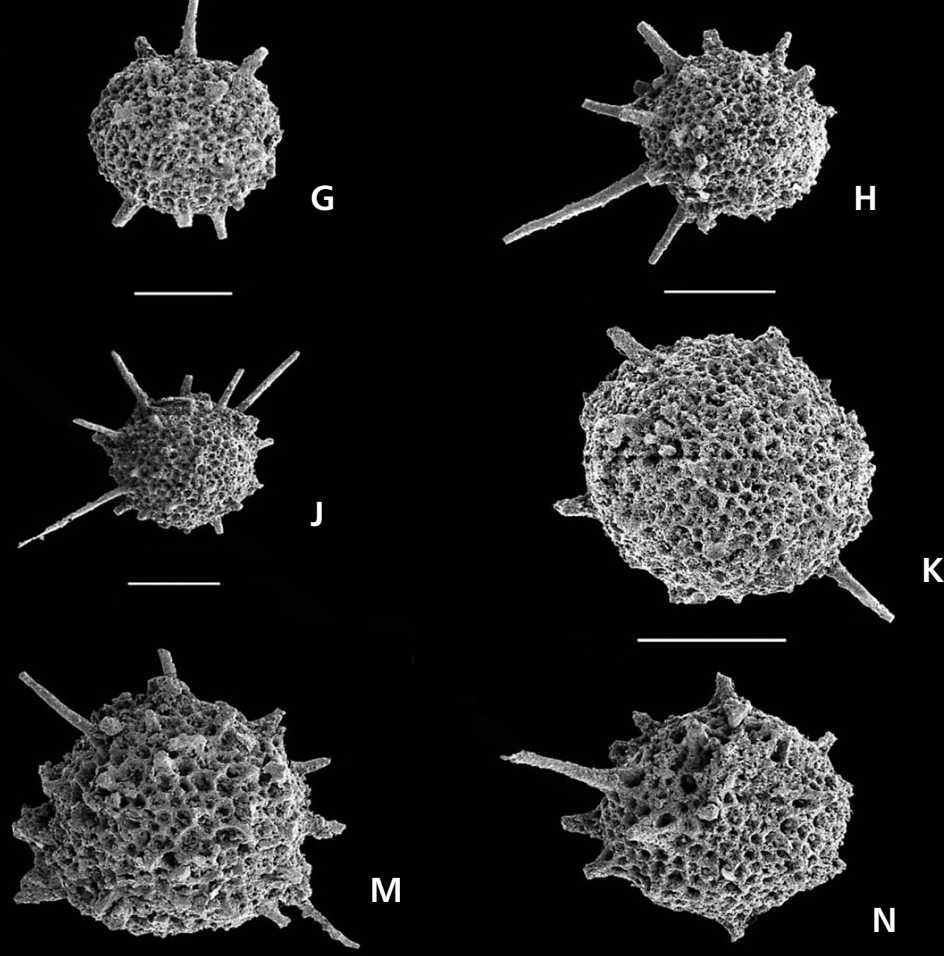

N
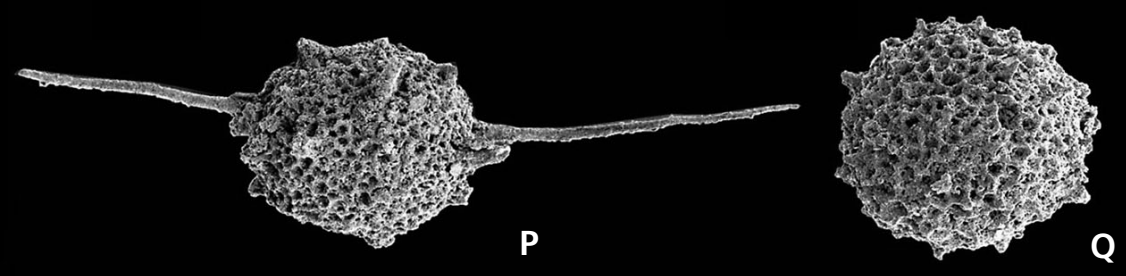
approximately $50 \%$ of the spine length. Distal half of spines are rod-shaped and circular in cross section. Pore frames are irregulary polygonal, approaching pentagonal, and measure 5 to $8 \mu \mathrm{m}$ diameter. This species differs from other species of Zadrappolus in the presence of few short conical external spines. Zadrappolus lunaris is similar to Z. yoshikiensis in external appearance; however, the former differs from the latter in having a larger cortical shell with smaller number of conical spines.

Range and occurrence. - Uppermost Silurian to Lower Devonian. Hitoegane areas and Yoshiki Formation in the Hida-gaien terrane; Marathon uplift in west Texas.

\section{Zadrappolus(?) nudus Kurihara, 2007}

Figure 13E-K, Q

1996 Oriundogutta sp. Aitchinson, Hada, Ireland \& Yoshikura, pp. 66, 67, pl. 2, fig. 14 .

2007 Zadrappolus(?) nudus Kurihara, pp. 230, 231, pl. 2, figs 11-14.

Remarks. - This species is easily distinguished from other species of Zadrappolus yoshikiensis by its very large cortical shell with only a few very small conical spines.

Range and occurrence. - Upper Silurian to Lower Devonian. Hitoegane area and Yoshiki Formation in the Hidagaien terrane; Yoshinozawa-guchi area in the Kurosegawa terrane.

\section{Zadrappolus(?) sp.}

Figure 13L-N

2007 Zadrappolus(?) sp. Kurihara, pp. 234, 235, pl. 2, figs 15,16 .

Remarks. - Large, spherical, irregular porous cortical shell with 13 to 19 short conical spines per hemisphere; spines are moderately deeply grooved in the proximal parts. This species is easly distinguished from other species of $\mathrm{Za}$ drappolus by its very large cortical shell with many conical spines. Zadrappolus(?) sp. differs from Z. yoshikiensis in bearing long and cylindrical spines. Zadrappolus yoshikiensis is distinguished from Zadrappolus spinosus and
Zadrappolus hitoeganensis by its numerous short, thin, cylindrical spines. Zadrappolus lunaris is similar to Z. yoshikiensis in external appearance; however, the former differs from the latter in having a larger cortical shell with large number of conical spines. But. Zadrappolus(?) sp. differs from Zadrappolus nudus in bearing a large number of conical spines.

Range and occurrence. - Upper Silurian to Lower Devonian. Hitoegane area and Yoshiki Formation in the Hidagaien terrane; Jingamori and Konomori areas in the Kurosegawa terrane.

\section{Genus Futobari Furutani, 1990}

Type species. - Futobari solidus Furutani, 1990.

\section{Futobari solidus Furutani, 1990}

Figure 11G-K

1990 Futobari solidus Furutani, p. 34, pl. 1, figs 1-4.

1996 Futobari solidus Aitchinson, Hada, Ireland \& Yoshikura, p. 65, pl. 6, figs 3,8 .

1997 Futobari solidus Umeda, p. 422, pl. 4, figs 14-17.

1998 Futobari solidus Umeda, figs 9-12.

2007 Futobari solidus Kurihara, p. 231, pl. 2, figs 17-21.

1990 Spumellaria gen. indet. sp. A Wakamatsu, Sugiyama \& Furutani, p. 174, pl. 8, figs 1a, b.

1990 Spumellaria gen. indet. sp. E Wakamatsu, Sugiyama \& Furutani, p. 175, pl. 8, fig. 5.

Remarks. - The cortical shell is single, spherical, latticed, and 100 to $150 \mu \mathrm{m}$ in diameter. Pores of the cortical shell are regular in shape and size. Furutani (1990) noted that this species has doubled medullary shells; the outer medullary shell is spherical and consists of an irregular mesh of bars, whereas the features of the inner medullary shell are not clear. Main spines are very long, thick, gently tapered from the proximal to distal parts, and five to seven in number. The proximal part of the spines is deeply grooved, and the middle and distal parts are circular in the cross section. This species is distinguished from Futobari morishitai $\mathrm{Fu}-$ rutani by possessing fewer main spines and slightly larger cortical shell diameter.

Range and occurrence. - Upper Silurian to Lower Devonian. Fukuji, Hitoegane areas and Yoshiki Formation in the

Figure 13. A-D - Zadrappolus lunaris Noble. A - horizon 14; B - horizon 4; C-horizon 3; D - horizon 6. • E-K, Q - Zadrappolus(?) nudus Kurihara. $\mathrm{E}$ - horizon 15; F - horizon 18; G - horizon 18; H - horizon 18; I - horizon 9; J - horizon 2; K - horizon 2; Q - horizon 7. • L-N - Zadrappolus(?) sp. Kurihara. L - horizon 20; M - horizon 19; N - horizon 19. • O, P -Futobari morishitai Furutani. O - horizon 17; P - horizon 15. • R - Ceratoikiscum armiger Furutani; horizon 17. $\bullet \mathrm{S}-$ Rotasphaera(?) sp.; horizon 17. Scale bars: $100 \mu \mathrm{m}$. 


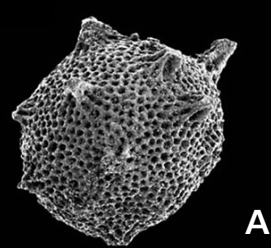

A

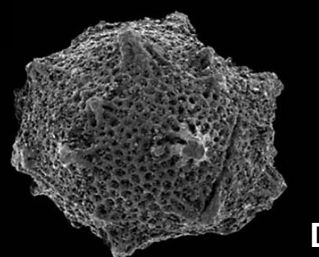

D

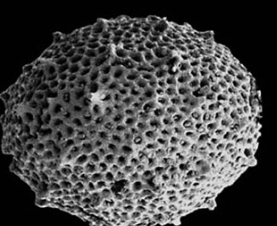

G

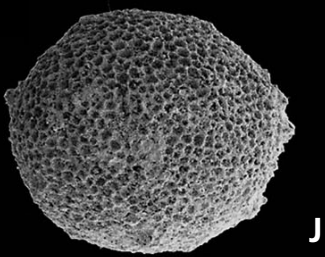

J

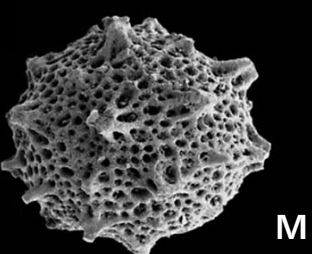

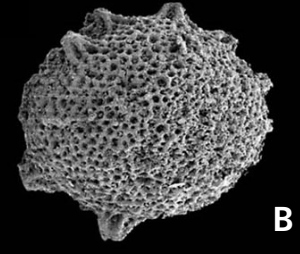

B

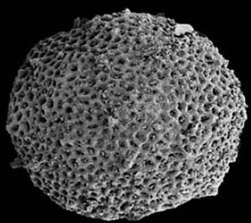

E

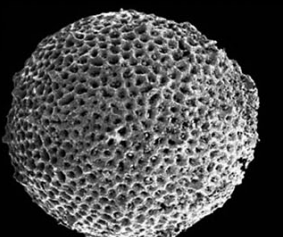

H

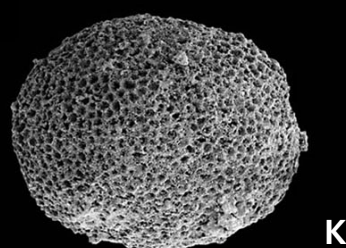

K

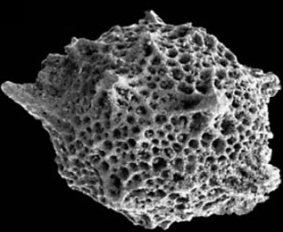

N
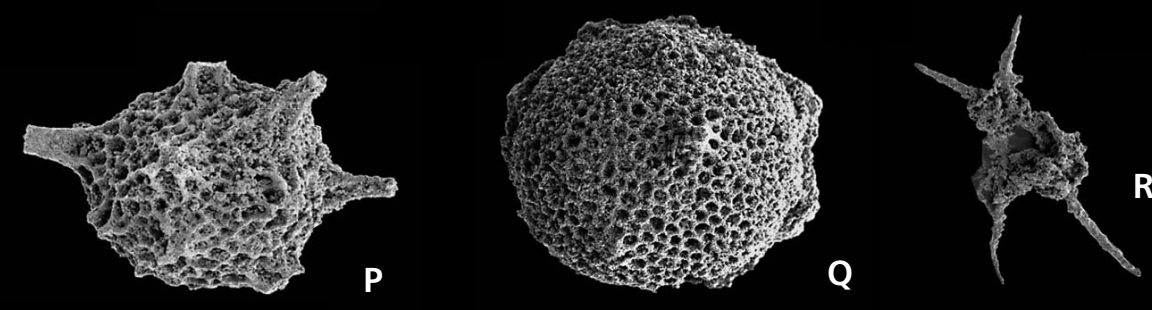
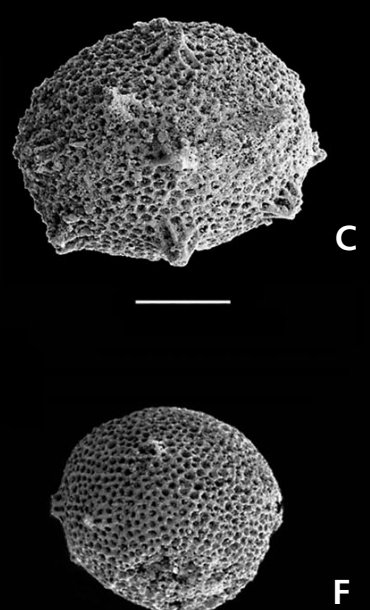

F
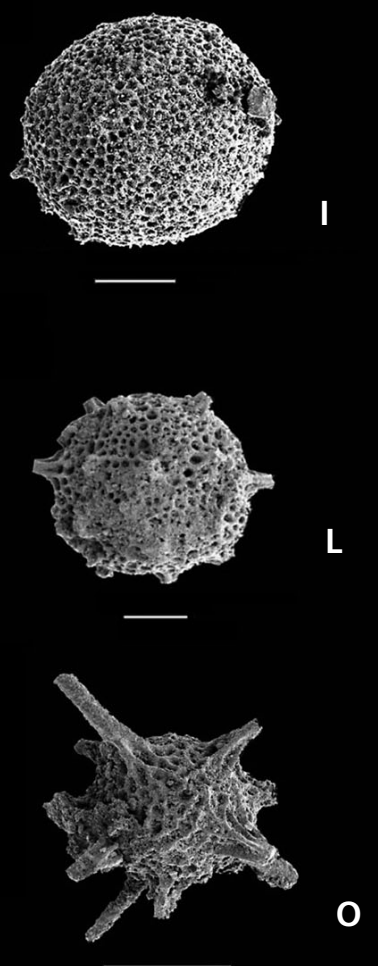

R

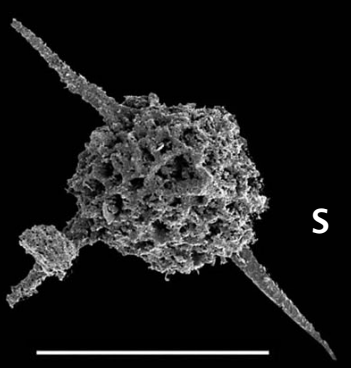


Hida-gaien terrane; Konomori and Jingamori areas of the Kurosegawa terrane.

Futobari morishitai Furutani, 1990

Figures 11L, M, 13O, P

1990 Futobari morishitai Furutani, p. 35, pl. 1, fig. 5, pl. 2, figs 1-3.

1997 Futobari morishitai Umeda, pp. 421-422, pl. 2, fig. 16; pl. 4, fig. 13 .

1998 Futobari morishitai Umeda, fig. 9-6.

2007 Futobari morishitai Kurihara, p. 231, pl. 2, figs 22, 23.

1996 Futubari sp. cf. F. morishitai Furutani, 1990. - Aitchinson, Hada, Ireland \& Yoshikura, p. 65, pl. 1, fig. 18; pl. 2, fig. 13; pl. 3, fig. 11.

Remarks. - This species characteristically has latticed moderately small cortical shell 150 to $200 \mu \mathrm{m}$ in diameter. Shell has numerous small round pores. The spines are four to six external per hemisphere. The proximal part of the spines is deeply grooved. The external spines are slightly thinner than those of Futobari solidus.

Range and occurrence - Uppermost Silurian to Lower Devonian. Fukuji, Hitoegane areas and Yoshiki Formation in the Hida-gaien terrane; Konomori, Yoshinosawa-guchi, and Jingamori areas in the Kurosegawa terrane.

Family Rotasphaeridae Noble, 1994, emend. MacDonald, 1998; Noble \& Maletz, 2000;

Won, Blodgetti \& Nestor, 2002

Genus Rotasphaera Noble, 1994, emend. MacDonald, 1998

Type species. - Rotasphaera marathonensis Noble, 1994.

\section{Rotasphaera sp.}

Figure 13S

1990 Secuicollacta sp. indet. Furutani, pl. 13, fig. 2.

2007 Rotasphaera sp. Kurihara, pl. 2, fig. 25.

Remarks. - The specimens four or more robust tapering spines observed on per hemisphere. The shell is single spherical, latticed, and $80 \mu \mathrm{m}$ in diameter. The specimens bear a strong morphological similarity to genus Rotasphaera. This genus was originally erected by Noble (1994) for taxa possessing a single lattice shell formed by the coalescence of two or more primary spine units (morphological terminology of this genus follows Noble
1994). Noble (1994) suggested that this genus is distinguished from the genus Secuicollacta Nazarov and Ormiston by having a smaller number of primary spines and more differentiation between primary and secondary spine morphology. However, subsequent taxonomic work by MacDonald (1998) shows that specimens belonging to the genus Secuicollacta have one ectopically placed spicule and additional primary spine units. As MacDonald (1998) pointed out, all species described as Secuicollacta by Furutani (1990) have no ectopic spicule and only primary spine units. Herein, I follow MacDonald's (1998) opinion and include the following three species within the genus Rotasphaera; namely, Secuicollacta itoigawai Furutani, Secuicollacta horrida Furutani, and Secuicollacta vulgaris Furutani.

Range and occurence. - Upper Silurian to Lower Devonian. Fukuji, Hitoegane areas and Yoshiki Formation in the Hida-gaien terrane.

\section{Genus Ceratoikiscum Deflandre, 1953}

Type species. - Ceratoikiscum avimexpectans Deflandre, 1953.

\section{Ceratoikiscum armiger Furutani, 1990}

Figure 13R

1990 Ceratoikiscum armiger Furutani, pp. 51, 52, pl. 12, figs 2-4.

1995 Ceratoikiscum armiger Amon, Braun \& Ivanov, p. 4, pl. 1, figs 1,2 .

1997 Ceratoikiscum armiger Umeda, p. 419, pl. 1, fig. 19; pl. 3, figs 15-17.

1998 Ceratoikiscum armiger Umeda, fig. 9.

1998 Ceratoikiscum armiger Kurihara \& Sashida, pl. 1, figs $11,12$.

2000 Ceratoikiscum armiger Kurihara \& Sashida, p. 63, pl. 1, figs 12,13 .

2007 Ceratoikiscum armiger Kurihara, pl. 2, fig. 29.

1996 Ceratoikiscum sp. Furutani, figs 5-7.

Remarks. - This species bears a strong morphological similarity to Ceratoikiscum armiger Furutani. Ceratoikiscum armiger differs from other species of the genus Ceratoikiscum by possessing a simple skeleton consisting of three rods and caveal ribs (morphological terminology of the genus Ceratoikiscum follows Wakamatsu et al. 1990).

Range and occurence. - Upper Silurian to Lower Devonian. Fukuji, Ise, Hitoegane areas and Yoshiki Formation in the Hida-gaien terrane; Konomori, and Yokokurayama areas in the Kurosegawa terrane; Southern Urals. 


\section{Acknowledgments}

We wish to thank Toshiyuki Kurihara at Niigata University, Japan for helpful discussion and advice. We are indebted to Hiroshi Hidaka at Hiroshima University, Japan, Tomokazu Hokada at National Institute for polar Research, Japan, Hidekazu Yoshida, Mamoru Adachi and Makoto Takeuchi at Nagoya University for valuable discussion and comments. We are grateful to Takenori Kato and Masumi Nozaki at Nagoya University for technical support on using SEM, EPMA and CL. We wish to thank Giles Clarke at the Natural History Museum, London for critical reading of the early draft of this paper. This work was supported by the RONPAKU (Dissertation Ph.D.) Program of Japan Society for the Promotion of Science. Special thanks go to Minjin Chuluun at Mongolian University of Science and Technology, Mongolia for helpful advice. This paper is a contribution to the IGCP 596 project.

\section{References}

Aitchison, J.C., Hada, S., Ireland, T. \& Yoshikura, S. 1996. Ages of Silurian radiolarians from the Kurosegawa terrane, Southwest Japan constrained by U/Pb SHRIMP data. Journal of Southeast Asian Earth Science 14, 53-70. DOI 10.1016/S0743-9547(96)00045-1

Aitchison, J.C. \& STRATFORD, J.M.C. 1997. Middle Devonian (Givetian) Radiolaria from Eastern New South Wales, Australia: a reassessment of the Hinde (1899) fauna. Neues Jahrbuch für Geologie und Paläontologie, Abhandlungen 203, 369-390.

Aitchison, J.C., David, A.M., Stratford, J.M.C. \& Spiller, F.C.P. 1999. Lower and Middle Devonian radiolarian biozonation of the Gamilaroi terrane New England Orogen, easthern Australia. Micropaleontology 45, 138-162. DOI $10.2307 / 1486110$

Amon, E.O., Braun, A. \& Ivanov, K.S. 1995. Upper Silurian radiolarians from the southern Urals. Geologica et Palaeontologica 29, 1-17.

Black, L.P., Kamo, S.L., Allen, C.M., Davis, D.W., AleinikofF, J.N., Valley, J.W., Mundil, R.M., Campbell, I.H., Korsch, R.J., Williams, I.S. \& Foudoulis, C. 2004. Improved ${ }^{206} \mathrm{~Pb} /{ }^{238} \mathrm{U}$ microprobe geochronology by the monitoring of a trace-element-related matrix effect; SHRIMP, ID-TIMS, ELA-ICP-MS and oxygen isotope documentation for a series of zircon standards. Chemical Geology 205, 115-140. DOI 10.1016/j.chemgeo.2004.01.003

Breemen, O. van, Davidson, A., Loveridge, W.D. \& Sullivan, R.W. 1986. U-Pb zircon geochronology of Grenville tectonites, granulites, and igneous precursors, Parry Sound, Ontario, 191-208. In Moore, J.M., Davidson, A. \& BAER, A.J. (eds) The Grenville Province. Geological Association of Canada Special Paper 31.

Claoué-Long, J.C., Compston, W., Roberts, J. \& Fanning, C.M. 1995. Two Carboniferous ages: a comparison of SHRIMP zircon dating with conventional zircon ages and ${ }^{40} \mathrm{Ar} /{ }^{39} \mathrm{Ar}$ analysis, 3-21. In Berggren, W.A., Kent, D.V., Aubrey, M.P. \& Hardenbol, J. (eds) Geochronology Time Scales and Global Stratigraphic Correlation. Society for Sedimentary Geology Special Publication 54.
Deflandre, G. 1953. Radiolaires fossils, 389-436. In Grasse, P.P. (ed.) Traité de Zoologie. Masson, Paris.

EhrEnBERG, C.G. 1875. Fortsetzung der mikrogeologischen Studien als Gesammt-Uebersicht der mikroskopischen Palaontologie gleichartig analysirter Gebirgsarten der Erde, mit specieller Rucksicht auf den Polycystinen-Mergel von Barbados. Königliche Akademie der Wissenschaften zu Berlin, Abhandlungen 1875, 1-225.

Furutani, H. 1990. Middle Paleozoic radiolarians from Fukuji area, Gifu Prefecture, central Japan. Journal of Earth Science, Nagoya University 37, 1-56.

Furutani, H. 1996. Evolution of Palaeoscenidiidae and Ceratoikiscidae (Radiolaria) in Late Devonian (Preliminary report), 71-84. In NodA, H. \& SASHIDA, K. (eds) Professor Hisayoshi Igo Commemorative Volume on Geology and Paleontology of Japan and Southeast Asia.

Gradstein, F.M., OGG, J.G. \& Smith, A.G. (eds) 2004. A Geologic Time Scale 2004. 589 pp. Cambridge University Press, Cambridge.

Horie, K., Hidaka, H. \& Gauthier-Lafaye, F. 2006. Elemental distribution in zircon: Alteration and radiation-damage effects. Physics and Chemistry of the Earth 31, 587-592.

Igo, H. 1990. Paleozoic strata in the Hida "Gaien" Belt, 41-48. In IChikawa, K., Hara, I., HadA, S. \& YAO, A. (eds) Pre-Cretaceous Terranes of Japan, IGCP Project No. 224: Pre-Jurassic Evolution of Eastern Asia.

Igo, H., Adachi, S., Furutani, H. \& Nishiyama, H. 1980. Ordovician fossils first discovered in Japan. Proceedings of the Japan Academy 56, 499-503. DOI 10.2183/pjab.56.499

KuRIHARA, T. 2003. Stratigraphy and geologic age of the Middle Paleozoic strata in the Kuzuryu Lake-Upper Ise River area of the Hida-gaien Terrane, central Japan. Journal of the Geological Society of Japan 109, 425-441. [in Japanese with English abstract] DOI 10.5575/geosoc.109.425

Kurihara, T. 2003. Early Devonian Palaeoscenidiidae (Radiolaria) from the "Yoshiki Formation" in the Fukuji area of the Hida-gaien Terrane, central Japan, and its biostratigraphy significance. Journal of the Geological Society of Japan 109, 635-647. [in Japanese with English abstract] DOI 10.5575/geosoc.109.635

KuRIHARA, T. 2004. Silurian and Devonian radiolarian biostratigraphy of the Hida Gaien belt, central Japan. Journal of the Geological Society of Japan 110, 620-639. [in Japanese with English abstract] DOI 10.5575/geosoc. 110.620

KuRIHARA, T. 2007. Uppermost Silurian to Lower Devonian radiolarians from the Hitoegane area of the Hida-gaien terrane, central Japan. Micropaleontology 53, 221-237. DOI 10.2113/gsmicropal.53.3.221

KuRIHARA, T. \& SASHIDA, K. 1998. Occurrence and significance of the Late Silurian and Early to Middle Devonian radiolarians from the Kuzuryu Lake district of the Hida Gaien Belt, Fukui Prefecture, central Japan. Journal of the Geological Society of Japan 104, 845-858. [in Japanese with English abstract] DOI 10.5575/geosoc. 104.845

KuRIhARA, T. \& SASHidA, K. 2000. Taxonomy of Late Silurian to Middle Devonian radiolarians from the Kuzuryu Lake district of the Hida Gaien Belt, Fukui Prefecture, central Japan. Micropaleontology 46, 51-71.

Kroner, A., O’Brien, P.J., Nemchin, A.A. \& Pidgeon, R.T. 2000. 
Zircon ages for high pressure granulites from South Bohemia, Czech Republic, and their connection to Carboniferous high temperature processes. Contributions to Mineralogy and Petrology 138, 127-142.

LI, H. 1994. Middle Silurian Radiolarians from Keerhada, Xinjiang. Acta Micropaleontologica Sinica 11, 259-272. [in Chinese with English abstract]

LuDwIG, K.R. 2008. Isoplot 3.6: A Geochronological Toolkit for Microsoft Excel. Berkeley Geochronology Center Special Publication, Berkeley 4, 77.

LuDwIG, K.R. 2009. SQUID 2: A User's Manual. Berkeley Geochronology Center Special Publication, Berkeley 2, 104.

MacDonald, E.W. 1998. Llandovery Secuicollactinae and Rotasphaeridae (Radiolaria) from the Cape Phillips Formation, Cornwallis Island, Arctic Canada. Journal of Paleontology $72,585-604$.

NAZARov, B.B. 1975. Lower and Middle Paleozoic radiolarians of Kazakhstan. Transactions of the Academy of Sciences of the USSR, Geological Institue, 1-203. [in Russian]

Nazarov, B.B. 1988. Paleozoic radiolaria. Practical manual of microfauna of the USSR. 232 pp. Nedra, Leningrad. [in Russian]

Nazarov, B.B. \& Ormiston, A.R. 1984. Tentative system of Paleozoic radiolaria, 64-87. In Petrushevskaya, M.G. \& STEPANJANTS, S.D. (eds) Morphology, ecology and evolution of Radiolaria. Nauka, Leningrad. [in Russian with English summary]

Nazarov, B.B. \& Ormiston, A.R. 1993. New biostratigraphic important Paleozoic Radiolaria of Eurasia and North America, 22-60. In Blueford, J.R. \& Murchey, B.L. (eds) Radiolaria of giant and subgiant fields in Asia. Nazarov Memorial Volume. Micropaleontology Press Special Publication 6.

Ninhara, T., TachiKawa, O. \& Horie, K. 2010. New desine megamount holder, application for extra terrestrial materials. International Association for Gondwana Research Conference Series 10, 59-60.

NobLE, P.J. 1994. Silurian radiolarian zonation for the Caballos Novaculite, Marathon uplift, West Texas. Bulletins of American Paleontology 106, 1-55.

Noble, P. \& Aitchison, J. 2000. Early Paleozoic radiolarian biozonation. Geology (Boulder) 28, 367-370. DOI 10.1130/0091-7613(2000)28<367:EPRB > 2.0.CO;2

Noble, P.J. \& MALETZ, J. 2000. Radiolaria from the Telychian (Llandovery, Early Silurian) of Dalarna, Sweden. Micropaleontology 46, 265-275. DOI 10.2113/46.3.265

Obut, O.T. \& ShcherbanenKo, T.A. 2008. Late Devonian radiolarians from the Rudny Altai (SW Siberia). Bulletin of Geosciences 83, 371-382.

DOI 10.3140/bull.geosci.2008.04.371

OdIN, G.S. 1994. Geological time scale (1994). Comptes Rendus de l'Academie des Science, Serie II 318, 59-71.

Pidgeon, R.T., Macambira, M.J.B. \& Lafon, J.M. 2000. $\mathrm{Th}-\mathrm{U}-\mathrm{Pb}$ isotopic systems and internal structures of complex zircons from an enderbite from the Pium Complex, Carajas
Province, Brazil: Evidence for the ages of granulite facies metamorphism and the protolith of the enderbite. Chemical Geology 166, 159-171.

DOI 10.1016/S0009-2541(99)00190-4

RÜST, D. 1892. Beitrage zur Kenntnis der fossilen Radiolarien aus Gesteinen der Trias und der Paleozoischen Schichten. Palaeontographica 38, 107-192.

StACEY, J.S. \& KRAmERS, J.D. 1975. Approximation of terrestrial lead isotope evolution by a two-stage model. Earth and Planetary Science Letters 26, 207-221.

DOI 10.1016/0012-821X(75)90088-6

StratFord, J.M.C. \& Aitchison, J.C. 1997. Lower to Middle Devonian radiolarian assemblages from the Gamilaroi Terrane, Glenrock Station, NSW, Austria. Marine Micropaleontology 30, 225-250. DOI 10.1016/S0377-8398(96)00027-8

Tsukada, K. \& TAKahashi, Y. 2000. Redefinition of the Permian strata in the Hida-gaien Tectonic Zone, Fukuji area, Gifu Prefecture, Central Japan. Journal of Earth and Planetary Science, Nagoya University 31, 1-35.

TSUKADA, K., TAKAHASHI, Y. \& OZAWA, T. 1999. Stratigraphic relationship between the Mizuyagadani and Sorayama Formations, and age of the Sorayama Formation, in the Hida-gaien Tectonic Zone, Kamitakara Village, Gifu Prefecture, central Japan. Journal of the Geological Society of Japan 105, 496-507. DOI 10.5575/geosoc. 105.496

Vavra, G., Schmid, R. \& Gebauer, D. 1999. Internal morphology, habit and U-Th- $\mathrm{Pb}$ microanalysis of amphibolite-togranulite facies zircons: Geochronology of the Ivrea Zone (Southern Alps). Contributions to Mineralogy and Petrology 134, 380-414. DOI 10.1007/s004100050492

UmedA, M. 1997. Late Silurian and Early Devonian radiolarians from the Konomori area in the Kurosegawa Terrane, Southwest Japan. Earth Science (Chikyu Kagaku) 51, 413-432.

UMEDA, M. 1998. Upper Silurian to Middle Devonian radiolarian zones of the Yokokurayama and Konomori areas in the Kurosegawa Belt, Southwest Japan. The Island Arc 7, 637-646. DOI 10.1046/j.1440-1738.1998.00215.x

Wakamatsu, H., Sugiyama, K. \& Furutani, H. 1990. Silurian and Devonian radiolarians from the Kurosegawa Tectonic Zone, Southwest Japan. Journal of Earth Science, Nagoya University 37, 157-192.

WILLIAMS, I.S. 1998. U-Th-Pb geochronology by ion microprobe, 1-35. In McKibben, M.A., Shanks III, W.C. \& Ridley, W.I. (eds) Applications of Micro-analytical Techniques to Understanding Mineralizing Processes. Reviews in Economic Geology 7.

Won, M.Z., Blodgett, R.B. \& Nestor, V. 2002. Llandoverian (Early Silurian) radiolarians form the Road River Formation of east-central Alaska and the new family Haplotaeniatumidae. Journal of Paleontology 76, 941-964. DOI 10.1666/0022-3360(2002)076<0941:LESRFT>2.0.CO;2

YASUI, T. 1984. On the pre-Silurian basement in the Yokokurayama lenticular body of the Kurisegawa Tectonic Zone. Chikyu Kagaku (Earth Science) 38, 89-101. [in Japanese] 